Illinois State University

ISU ReD: Research and eData

Theses and Dissertations

$11-11-2013$

\title{
Why do teachers hate ain't? Eighteenth-century ideologies and attitudes in twenty-first-century classrooms
}

Robin Elise Halsey

Illinois State University, rehalse@ilstu.edu

Follow this and additional works at: https://ir.library.illinoisstate.edu/etd

Part of the Education Commons, and the Other Languages, Societies, and Cultures Commons

\section{Recommended Citation}

Halsey, Robin Elise, "Why do teachers hate ain't? Eighteenth-century ideologies and attitudes in twentyfirst-century classrooms" (2013). Theses and Dissertations. 70.

https://ir.library.illinoisstate.edu/etd/70

This Thesis is brought to you for free and open access by ISU ReD: Research and eData. It has been accepted for inclusion in Theses and Dissertations by an authorized administrator of ISU ReD: Research and eData. For more information, please contact ISUReD@ilstu.edu. 


\title{
WHY DO TEACHERS HATE AIN'T? EIGHTEENTH-CENTURY IDEOLOGIES AND ATTITUDES IN \\ TWENTY-FIRST-CENTURY \\ CLASSROOMS
}

\author{
Robin E. Cross Halsey
}

123 Pages

December 2013

This thesis investigates the impact of various historical events on the development of the English language and its grammar. Specifically, this project highlights how the ideologies about language held by eighteenth-century grammar-writers have influenced the pedagogical approach of teachers of English, persisting into the twenty-first century. Further, the rationale behind these language ideologies is explored in order to gain important insights into the seemingly prescriptive nature of the majority of grammar texts produced in the eighteenth century and beyond.

The origins of four particular points of grammar and usage that are commonly attacked by teachers, grammarians, and others are examined. The chapter on ain't explores the mystery behind the word's former respectability and its descent into the realm of unacceptability, which led to labels such as barbarism and vulgarism. The chapter on attitudes toward variant pronunciations of ask reveals the surprising etymology of the word while tracing the history of its popular usage over time. The chapters on multiple negation and preposition stranding relate the histories of two of 
many examples of prescriptive rules appearing in eighteenth-century normative grammars.

Throughout the last three centuries, many theories about linguistics and grammar teaching have been advanced. Despite our current knowledge about the nature and function of language and the realities of language change and variation, however, debates over the teaching of grammar continue. Unsure about the best ways to present material that may appear on standardized tests, teachers may simply continue the cycle begun centuries earlier, and encourage students to memorize particular rules of English grammar. This thesis suggests that an appropriate alternative for today's society may be a more historically and linguistically informed, comprehensive approach to teaching grammar and usage — a pedagogy that emphasizes clear communication instead of the rigid adherence to a set of rules. 
WHY DO TEACHERS HATE AIN'T? EIGHTEENTH-CENTURY

IDEOLOGIES AND ATTITUDES IN

TWENTY-FIRST-CENTURY

CLASSROOMS

ROBIN E. CROSS HALSEY

A Thesis Submitted in Partial

Fulfillment of the Requirements

for the Degree of

MASTER OF ARTS

Department of English

ILLINOIS STATE UNIVERSITY

2013 
(C) 2013 Robin E. Cross Halsey 
WHY DO TEACHERS HATE AIN'T? EIGHTEENTH-CENTURY

IDEOLOGIES AND ATTITUDES IN

TWENTY-FIRST-CENTURY

CLASSROOMS

ROBIN E. CROSS HALSEY

COMMITTEE MEMBERS:

K. Aaron Smith, Chair

Susan M. Kim 


\section{ACKNOWLEDGMENTS}

The writer wishes to thank her family and friends for the love and patience they have demonstrated during the many stages of this project. The writer also wishes to express her appreciation and gratitude to her thesis committee, Dr. K. Aaron Smith and Dr. Susan Kim, for their encouragement as well as their valuable comments and criticisms on the numerous drafts leading up to the finished work. Further, without the inspiration, leadership, and excellence in teaching provided by the faculty and staff of the Department of English and the English Language Institute at Illinois State University, this effort might never have been undertaken. A warm thank you goes to Dr. Jim Kalmbach, Dr. Hyun Sook Kang, Dr. Susan Burt, Dr. Lisya Seloni, Dr. Kasia Stadnik, Dr. Chris DeSantis, Diane Smith, Courtney Grose, the students at the English Language Institute, and the many fellow ISU students who have directly or indirectly contributed to the writer's interest in this project.

Finally, this thesis is dedicated to Mrs. Mourine Ehmcke, Mrs. Evelyn Kaufman, and Miss Edwina Patton, three women who made a difference in the world by teaching English.

R.E.C.H. 


\section{CONTENTS}

Page

ACKNOWLEDGMENTS

CONTENTS

TABLES

CHAPTER

$\begin{array}{ll}\text { I. INTRODUCTION } & 1\end{array}$

Statement of the Problem 1

Hypothesis $\quad 3$

Definition of Terms 4

Limitations of the Analysis $\quad 7$

Methodological Design $\quad 8$

II. GENERAL LITERATURE REVIEW 10

A Brief History of English Grammar 10

A Look at the Diachronic History of Grammar:

Where Did the Idea of a Standard Come From? 10

III. IDEOLOGIES BEHIND ENGLISH GRAMMAR “RULES” 32

IV. THE PROBLEM WITH MULTIPLE NEGATION 53

V. THE MYSTERY OF AIN'T 66

$\begin{array}{lll}\text { VI. } & \text { THE AKS ATTITUDE }\end{array}$

VII. NEVER END A SENTENCE WITH A PREPOSITION? 91

$\begin{array}{lll}\text { VIII. } & \text { SUMMARY AND PEDAGOGICAL IMPLICATIONS }\end{array}$

$\begin{array}{lr}\text { REFERENCES } & 112\end{array}$ 


\section{TABLES}

Table $\quad$ Page

1. Forms of Ask, 1366-1697 84 


\section{CHAPTER I}

\section{INTRODUCTION}

\section{Statement of the Problem}

In a half-century old book called Teaching English Grammar, I read that "English grammar has a useful part to play in the training of young people to use their language effectively" but that teachers "need help in determining exactly what is meant by the term [grammar], what content it does and does not include, for what purposes it is properly to be used, and what outcomes may be expected from its use" (Pooley 1957:vii). Teachers were confused fifty-odd years ago, and they appear to be even more confused today. Even the International Reading Association and the National Council of Teachers of English (IRA/NCTE 1996:6) recognize that "teachers often receive conflicting messages about what they should be doing" to meet the demands of educational reforms and mandates. Despite pressure to try new teaching strategies in hopes of raising student scores on achievement tests, teachers are "discouraged from making their instructional practices look too different from those of the past" (12). This conflict leads many teachers to stick with old-fashioned, "tried and true" teaching methods, often developing a hyper-vigilant focus on the rules of English grammar that they were taught, assuming that if the rules were good enough for them to learn, they must be good enough for the students of the $21^{\text {st }}$ century. 
The problem is that as our society has changed, so have some of our ideologies about grammar. Like it or not, our language is constantly evolving (as living languages do), and some teachers have trouble recognizing (and dealing with pedagogically) the changes. Some teachers of English cling to their old grammar handbooks and try to ignore the fact that what is written in their standard textbook may not be applicable for today's linguistic realities. Others wonder if they can accept nonstandard usages in speech while requiring the conventions of standard grammar in written work.

My son Sam came home from middle school one day and announced that his English teacher kept yelling at everyone for saying "ain't." He quoted her as saying that they should not say "ain't" because "ain't is not a word." This may not be what Pooley had in mind back in 1957, but in the school systems of today this type of issue arises constantly. In my experience, both as a teacher in an urban high school, and as a parent of two former high school students and two students still in the middle and high school years, I have observed that some teachers of English seem to have in mind particular ideas about what constitutes acceptable English grammar, and what does not. These ideas are presented as hard and fast "rules" that must be understood, memorized, and put into practice in all forms of language use, whether in casual speech or formal writing. Students who disregard the "rules" are subject to oral correction by the teacher (sometimes with a less-than-favorable tone), or written commentary (in my day, these were scribbled in red ink, an unfortunate choice of color due to the obvious connotation).

This thesis is designed to contribute to our knowledge of the complexities that make up the grammar of English in the United States today. Specifically, this project endeavors to investigate how some of the grammar ideologies that emerged during the 
seventeenth and eighteenth centuries have influenced the attitudes (and teaching practices) of teachers of English (among other persons in society) in the twenty-first century. In addition, the following pages will offer insight into the origins of four particular points of grammar and usage that are commonly attacked by teachers, grammarians, and the like. Some implications of prescriptivist attitudes among teachers of English in U.S. classrooms will be discussed, and suggestions for a more historically and linguistically informed approach will be offered.

\section{Hypothesis}

The prescriptive attitude toward English grammar emerged during the decades immediately preceding the push for the reform of the English language, which began in the $17^{\text {th }}$ century but became a central concern during the $18^{\text {th }}$ century. The desire to establish a codified written language was dominated by scholars and writers who, in their anxiety about the many social, political, and cultural changes they had observed over the previous few centuries, saw a standard language as an important step toward national unity and stability. The process of creating a "standard" of grammar was often based on or influenced by the rules of Latin, not on patterns of acceptable or "correct" usage of English, even when those patterns had demonstrated their acceptability or perceived correctness over time. As scholars and professional educators, teachers of English should be aware of the historical background of the grammar they purport to teach, and at the very least, they should acquaint their students with the concept that our language (as well as its grammar) is alive, is continuously changing, and is not broken. 
Because English is a living language, it is reasonable to expect that standards that were created centuries ago, sometimes based on illogical premises, may not all be any more appropriate today than they were centuries ago. And furthermore, given what we now know about language change, the role of language in the formation of identity, the sociolinguistic dimensions of language, etc., it seems logical that teachers of English should proffer their students a comprehensive learning experience-one that combines linguistic insights from the past with the current focus on communication. Now more than ever we need to communicate effectively in many types of forums with individuals from a variety of cultural and socio-economic backgrounds. Today's teachers must recognize this reality and apply its message to their language instruction. By offering students the opportunity to explore, discuss, and examine critically some of the prescriptive grammar rules of the eighteenth century, teachers of English may foster an environment in which students learn not solely by rote memorization of rules and concepts, but by investigating for themselves, by making discoveries, and by effectively presenting these ideas to others.

\section{Definition of Terms}

What do we mean by "grammar," anyway? Does it refer to speech, or only to writing? Does it include spelling and pronunciation? Is one type of grammar superior over the other? For educators such as my son's English teacher, prescriptive grammar may seem attractive because correct and incorrect usages are outlined in a list of rules, making the task of teaching a "black or white" proposition. A student either uses the 
language correctly, resulting in a positive result (a good grade), or he uses it incorrectly, resulting in a negative result (a bad grade).

Throughout the centuries many definitions have been presented, which helps to explain the confusion that many current teachers of English face. Michael (2010:37) sums up the effects of the varying perceptions of grammar over time:

It can be seen within the tradition, and more clearly within the development of the English grammars, how the term grammar, originally (however it was defined) the name of a group of related literary and linguistic studies, was increasingly restricted in its application, but never entirely confined, to a system of categories used in linguistic analysis. Nevertheless it carried, and still carries, much of its original connotation: it is felt to be a term with a far wider meaning than that which a considered definition would propose or an elementary textbook illustrate. Grammar, in fact, is thought of in some contexts as applying solely to the analysis of linguistic structure, in others to wider questions of usage, tone and style. It is perhaps the vaguest term in the schoolmaster's, if not the scholar's vocabulary. This condition leads to confused teaching.

It may be useful, then, to compose a working definition of grammar, one that will suit the purpose of this thesis, and one that will begin to satisfy Pooley's (1957) dictate regarding the needs of teachers. Since this thesis is concerned with ideologies that led to prescriptivist attitudes toward written and spoken language, our working definition of grammar, therefore, must involve these key points. Also, since we are examining the origins of four specific forms or usages that were considered acceptable at some point in 
the history of the language, our definition should include some mention of word forms or inflections, the order of words in a sentence or their relationship to each other, the acceptability of particular usages, and a reference to time and place. Additionally, since the message of the thesis was inspired by the condemning words of an English teacher against her pupils' use of ain't, it seems appropriate to include the terms standard and nonstandard. Hollander (1993:269) refers to 'standard English' as "generally accepted norms of grammar and usage."

We may want to begin by considering the differences between prescriptive and descriptive grammar. Greenbaum (1988:25) defines prescriptive grammar as "a set of rules about language that tell speakers or writers what they should use or not use." Descriptive grammar, conversely, reflects the way in which language is used; more specifically, House \& Harman (1950:11) define it as "a study of established facts and usages as they exist at a given time." (See also Sayce's 1910 definition of grammatical propriety as 'the established usage of a particular body of speakers at a particular time in their history...' quoted in Pooley 1957:4).

The definitions of grammar offered by other reputable sources are suitable for their unique purposes, and are also suitable for our consideration in composing a working definition for the purpose of this thesis. For example, the Oxford English Dictionary [OED] (Oxford University Press 2011) defines grammar as:

That department of the study of a language which deals with its inflectional forms or other means of indicating the relations of words in the sentence, and with the rules for employing these in accordance with established usage; usually including also the department which deals with 
the phonetic system of the language and the principles of its representation in writing. Often preceded by an adj. designating the language referred to, as in Latin, English, French grammar.

Additionally, Huddleston \& Pullum (2002:3) point out that

[a] grammar of a language describes the principles or rules governing the form and meaning of words, phrases, clauses, and sentences. As such, it interacts with other components of a complete description: the phonology (covering the sound system), the graphology (the writing system: spelling and punctuation), the dictionary or lexicon, and the semantics.

Martin \& Rulon (1973:7) note that to a linguist, a grammar "is a formal and explicit description of [a] language." In comparison, they note that "the purist" sees grammar as "a description of the language as it ought to be spoken or written" (40), and they further comment that "to most people grammar means linguistic etiquette, observing certain prescribed rules of usage" (7). (Italics mine).

For the purpose of this thesis, however, the following working definition will suffice: Grammar is the spoken or written representation of both standard and nonstandard usages (on the levels of morphology and syntax) operating in the English language in a particular place and time. The study of grammar, then, may involve analysis and comparison of both formal and informal variations in usage.

\section{Limitations of the Analysis}

Much has previously been written about the history of the English language. This thesis does not presume to attempt a revision of those histories, nor does the writer plan 
to offer an alternate theory of the history of our "mother tongue." This project is simply an attempt to present, in a narrative fashion, a synopsis of some of the cultural, historical, and sociolinguistic events that have influenced the attitudes of persons in authority during the seventeenth and eighteenth centuries. Further, this thesis examines some of the effects that prescriptive attitudes of grammarians of these earlier centuries continue to have on the teaching of grammar in the twenty-first century. While some of the cultural and historical information that has been provided may cover a broader scope than is absolutely necessary, these details have been included in order to offer the reader a unique perspective toward understanding the effects of historical events on current teaching regarding the grammar and usage of English in the United States of America.

\section{Methodological Design}

This thesis consists of a review of literature treating the history of English, to examine some of the historical, social, and cultural events that have contributed to the emergence of the grammar of English that we currently use (and teach) in the United States. The chapters that follow explore the historical backgrounds of a few specific examples of grammar or usage (the contraction ain't, the concept of double or multiple negatives, the proscription against using a preposition at the end of a sentence, and the ask/aks controversy) and discuss some of the contemporary attitudes regarding these particular items.

These examples were chosen based on a few factors. First, all four were considered acceptable spoken and written usage at some point in the history of the language. The contraction ain't and the pronunciation of ask as aks represent two of 
many examples of nonstandard English that are in current use among many individuals today. The use of ain't is also commonly seen today in some examples of multiple negation. If we look at what these three items have in common, we might notice that they are often referred to as features of one or more dialects. The concept of multiple negation also shares with the proscription against preposition stranding the legacy of being specifically discussed in well-known passages of eighteenth-century normative grammars.

Evidence will be provided to illustrate various additional commonalities among these four points of usage and grammar. Sample literary passages illustrating the historical acceptability or treatment of the points in question are cited. In addition, the treatment of these points of grammar or usage by some of the grammarians of the seventeenth and eighteenth centuries will be compared to that of more recent "authorities" to determine how these particular "rules" have changed (or how their presentation differs). The thesis also discusses how the process of the standardization of the English language has affected these four points of grammar or usage. The concluding remarks focus on the pedagogical implications of my findings. 


\title{
CHAPTER II
}

\section{GENERAL LITERATURE REVIEW}

\author{
A Brief History of English Grammar \\ A Look at the Diachronic History of Grammar: Where Did the Idea of a Standard Come \\ From?
}

If one is unfamiliar with the history of the English language, he or she might assume that grammar rules that are commonly cited today have always been part of the language. That type of thinking, however, fails to recognize the fact that as a society changes and evolves, so does its language and its complex ideologies regarding language. Much has been written about the development of the English language. The following brief synopsis provides an overview of the history that has led to the dialects and varieties of English in use today.

It is widely accepted that the English language, as we know it, had its origins in England. But that is not the whole story. Millward (1996) relates that the story actually began thousands of years earlier, possibly between 5000 B.C. and 3000 B.C., in faraway lands with a reconstructed language known as Indo-European. Unfortunately, written records of the language history do not exist, and while historians have put together a prehistoric linguistic timeline that traces back a few thousand years, we have no way of knowing exactly what the Indo-European language looked or sounded like prior to 
around 1500 B.C. Pyles \& Algeo (1993:14) offer A.D. 700 as the approximate date of the beginning of "the documented history of the English language," but Millward (1996:77) offers that A.D. 450 is typically given as the year in which the era known as Old English began, based on the Venerable Bede's written records describing the arrival of the "Angles, Saxons, and Jutes" on the island occupied by Celtic-speaking peoples, who had likely arrived almost a millenium earlier.

These Germanic immigrants settled in the southern regions of Britain, a country which had been occupied for the preceding four centuries by representatives of the Roman Empire (until they were summoned back to Rome). As more of their Germanicspeaking countrymen left the Continent and joined them on the island, the Germanic population of Britain spread further north and west, forcing the Celtic "natives" even more inland. As one would expect, the groups of immigrants intermingled, and while each group may have tried to settle with their own "tribes" in separate sections of the island, they shared speech patterns that were largely mutually comprehensible and as these groups coalesced into a single nation, so too their languages merged into a single linguistic identity. Schmitt \& Marsdon (2006:22) point out that this language was eventually known as "Englisc" (English) after the Angles, and the country was called "Englalond."

Using the dates of significant events that influenced change in aspects of the language, historians have divided the stages of the development of the English language into four main periods: Old English, Middle English, Early Modern English, and Modern English (which is sometimes divided further into two categories: Late Modern English and Present Day English--PDE). 
"Old English" refers to the language used in England between A.D. 450 and A.D. 1100. In some ways this language seems very similar to Latin. For example, Old English, like Latin, is a highly inflected language. An inflected language is one in which the endings of the words change based on the function of the word in a sentence. If we were to look at a passage from a manuscript of this era we might find that the words look somewhat like the English we are used to, but unless we have studied Old English vocabulary and grammar, reading and understanding the passage would undoubtedly pose great difficulty.

In this respect, reading Old English is like trying to read a foreign language. A few words look familiar, but the spelling may appear unusual, even more so than the current British English practice of including a $<\mathrm{u}>$ in such words as honor (<honour $>$ ) and color (<colour>). In addition, the word order that we have grown accustomed to appears jumbled. Instead of the familiar pattern of Subject + Verb + Object (SVO), our Old English passage presents sentences in a variety of word orders, and as Millward (1996) notes, often in a less rigid structure than Present-day English (PDE).

Many of the features that were present in Old English had diminished or disappeared by the Middle English stage of the language (A.D. 1100 to A.D. 1500). For example, as Millward (1996) comments, the varied word orders common in Old English lessened, becoming more like the patterns found in PDE clauses. This was important because most of the inflections that had characterized OE had been dropped by the beginning stages of the ME period, and a more rigid word order developed. The two inflectional endings for nouns that remained at the beginning of the Early Modern 
English stage are easily recognized by modern speakers of English: possessives and plurals.

During the Middle English stage of English history, however, several events occurred that altered the pace of language change, and perhaps the origin of standard English. After the Norman invasion in 1066 and the death of King Harold at the Battle of Hastings, William of Normandy was crowned as the new king. The next few centuries saw the ruling upper class and the members of the English court speaking Norman French, which Leith $(2003: 26)$ refers to as "the Scandinavianised French of the Norman elite," while the majority of the rest of the population still spoke English. Latin was used as a scholarly and a religious language.

It was not long before the status of French in England changed, however. This development came about gradually, beginning with the loss of Norman lands by England's King John in the early thirteenth century. Millward (1996:144) indicates that while the loss of Norman lands in 1204 led to "a predictable decline of interest in France and French among those Anglo-Norman landholders who had opted to stay in England" during the next approximately 150 years certain "conditions were contributing to the rise in use and prestige of English."

One of these 'conditions' was the "increased communication among English speakers of the various regions" as described by Millward (1996:144). Apparently, by the latter part of the eleventh century it had become fairly common that people who spoke varying dialects of English would meet and interact while traveling abroad or while taking pilgrimages to the Holy Land. This type of contact "led to a smoothing out of the 
most striking dialectal differences and to the beginnings of a new standard English, based on the London dialect but including features from all dialectal areas" (144).

Another 'condition' that contributed to the rise in the use and the prestige of English was the adoption of English as the language of instruction in schools. Millward (1996:144) reports that "for about three hundred years after the Conquest, French was the language in which Latin was taught in the schools but by the late fourteenth century, English was the normal medium of instruction."

English may have taken over as the language of instruction in schools, however, French was still "the official language in England until well into the second half of the fourteenth century" (144) when English was established as "the official language of legal proceedings" (145), even though as Corrie (2008:99) points out, "records of legal proceedings were still kept in French—English was not used for this purpose until the seventeenth century..." In spite of this, the statute which in 1362 had decreed the use of English in the courts "gave the English language a validation that it had previously lacked, and this in turn may have stimulated the use of the language in other spheres" (99).

But it was the Black Death, the pestilence that between 1348 and 1351 killed an estimated one-third of England's population of four million people, which Bragg (2011:60) says "set in train a series of social upheavals which would speed the English language along the road to full restoration as the recognized language of the natives." Bragg (2011:60) details some of these 'upheavals': first, "a disproportionate number of the clergy" had lost their lives due to the plague, "thus reducing the grip of Latin all over the land." Next, Bragg notes that "[m]any of their replacements were laymen, sometimes 
barely literate, whose only language was English.” Bragg (2011:63) even suggests that the plague was instrumental in the establishment of English "as a language of official business" since the law permitting the use of English was passed when those in power realized that "many of the educated lawyers, like the clergy, had died in the plague." Another effect of the Black Death was that some areas of England experienced severe labor shortages. Workers who had somehow survived the plague campaigned for and received higher pay and better working conditions than they had ever had before. Also, many peasants left their farms to venture to larger towns and cities where they could obtain better-paying jobs. Baugh \& Cable (2002:142) point to this period as a time of "improvement in the condition of the mass of the people and the rise of a substantial middle class." History has born out the concept that a language's prestige "is largely determined by the importance of the people who speak it.” Baugh \& Cable (2002:143) summarize as follows: "By and large, the effect of the Black Death was to increase the economic importance of the laboring class and with it the importance of the English language which they spoke."

While the Black Death essentially cleared the way for English to reclaim its status, still another event, a longstanding war between England and France, advanced English even further toward prominence and high standing in the country. Judge (2009:110) reports:

By the end of [the] $13^{\text {th }}$ century, a distinct anti-French sentiment had begun to circulate in society—partly due to political friction between the two countries. Pushing the English patriotic button naturally led to promotion of the native language over the rival language. During the 14th 
century King Edward III even forbade his soldiers from speaking French in his army. They were fighting the French (The Hundred Years War).

The timing of these events played an important part in the confirmation of English as a language that was becoming increasingly worthy of respect. Millward (1996:145) even comments that the Black Death and the Hundred Years War effectively "assured the resurgence of English in England.” However, as Baugh \& Cable (2002:153) note, one matter remained. The final "step that the English language had to make in its gradual ascent was its employment in writing."

Following the Black Death and the Hundred Years War and the social changes that came about as a result, English "re-emerged" at last, as is evidenced by the production of major literary works such as Chaucer's Canterbury Tales and the Wycliffite translations of the Bible. We will now take a closer look at the role these works played in the progression of English's acceptability as a written language.

White (2009:68) notes that modern scholars look at Chaucer as "the best known author of the Middle English period," but it is important to understand, as Fisher (1992:1) has commented, that Chaucer's "success was gradual, not immediate, and its process is a fascinating glimpse into cultural history." Geoffrey Chaucer grew into young adulthood during the first quarter of The Hundred Years War. White (2009:68) tells us that "Chaucer was probably among the first students who were instructed to translate their Latin into English" instead of French, "a change brought on by the new feeling of patriotism due to the war." Perhaps Chaucer was emboldened by a sense of nationalism when he chose to compose his poetry in English, rather than French or Latin, a decision which Fisher (1992:1) calls “Chaucer's experiment.” Perhaps he imagined doing 
something great for his country by demonstrating that his mother tongue was a language worthy of literary writing. Or perhaps he thought that English was the ideal medium and his poetry the ideal outlet for, as Fisher (1992:152) notes, "[h]is satirical exposure of the corruption of religious orders." Whatever his motivation, Chaucer exhibited "courage" by writing "poetry in English for a French-speaking court" (1).

White (2009:68) notes that Chaucer's use of English "brought awareness to commoner and noble alike that the English language was packed with potential for great writing." This was significant because as Judge (2009:110) comments, "up to this time English had really been considered a low and vulgar language for literature." Baugh \& Cable (2002:153) remind us that it had only been a few years since the "time when most people who could write at all could write Latin, [due] partly to its international character, and partly to the feeling that it was a language that had become fixed while the modern languages seemed to be variable, unregulated, and in a constant state of change."

This ideology about English and its unsuitability as a literary language extended from secular writings to the religious realm as well. Bragg (2011:76) tells us that at the beginning of the fourteenth century in England "[t]here was no Bible in English." No complete Bible, that is. Bragg explains that "[t]here had been some piecemeal translations of the Gospels and parts of the Old Testament in Old English and there were Middle English versions of the Psalms." White (2009:70) reports that the translation that Wycliffe and several of his followers produced from Latin "was the very first complete Bible in the English language." Barber, Beal \& Shaw (2013) date the likely completion of the Wycliffite translations at a few years before Wycliffe's death in 1384. But this achievement was not welcomed by everyone. Wycliffe had not simply translated the 
Bible from one language into another. He had a larger purpose in mind-the reforming of longstanding religious practices which required educated clergy to interpret the scriptures for those individuals lacking a Latinate education. Bragg (2011:80) suggests that by offering the Word of God in a language that common people could understand, and by arguing that "the Bible was the sole authority for religious faith and practice and that everyone had the right to read and interpret scripture for himself," Wycliffe was seen by many Church leaders as attempting to undermine the authority of the Holy Roman Catholic Church and to attack many of the beliefs and practices of the Church. Bragg (2011:79) further writes:

From within the sanctioned, clerical, deeply traditionalist honeyed walls of Oxford, Wycliffe the scholar launched a furious attack on the power and wealth of the Church, an attack which prefigured that of Martin Luther more than a hundred years later.

But Corrie (2008:110) indicates that the Wycliffite translations reveal more than Wycliffe's attempt to unlock the mysteries of the scriptures to the masses; these translations also represent "[ $[\mathrm{t}] \mathrm{he}$ most widely attested example of a standardized variety of English from the fourteenth century..." Corrie (2008:110) clarifies by saying that this variety "does not seem to have been formulated or written in London, but in the central Midland region which was providing the English of London with so many features around the same time. This variety is usually called 'Central Midlands Standard'...” Corrie (2008:110-111) goes on to say that this dialect is used in most of the large number of writings which were produced to defend and propagate the teachings of Wyclif and his 
followers, partly because the central Midland area, the great hotbed of Wycliffite belief, appears to have been where many Wycliffite tracts were copied.

Corrie (2008:111) also comments that this dialect may have been used "for strategic reasons, since it lacked the barrier of incomprehensibility to many with which northern and southern dialects were charged." It is interesting to note that this dialect eventually became obsolete, which Corrie (2008:111) suggests was a result of "the proscription of the material for which it was chiefly used: Wyclif's beliefs were condemned by the Church as heretical, and the Wycliffites were persecuted especially viciously in the rein of Henry V (1414-22)."

As we have seen, the rise of the prestige of English was a gradual process which came about as a consequence of many historical events and the social changes that followed. The next step in the development of English was the establishment of a dialect that would become the standard. The fifteenth century proved ready for the challenge.

The introduction of the printing press in England in 1476 by William Caxton was pivotal in the increased emphasis on literacy throughout England. Those in the low and middle classes (whose lifestyles did not permit the luxury of a "classical education" and therefore knew only spoken English) could now have access to books and other materials in a language they could understand. (Of course, for many people books were still costprohibitive, but pamphlets and magazines were popular, and lending institutions offered materials as well.) And because printers had set up shop in the busy metropolitan area of London (a city whose visitors spoke dialects from all over the country), the English that 
appeared in print represented the London dialect, which had emerged as "the new standard in Middle English," according to Millward (1996:146).

The way in which the London dialect had emerged as the 'standard' has become the subject of some discussion in recent times. Fisher (1996:9) comments that many scholars have seemingly accepted the emergence of a standard dialect of English for written and spoken language as having occurred "by a kind of osmosis..." He refers to the work of language historians who "assumed that regularity developed simply as a convenience with the accumulation of literacy, was eventually imposed by the decisions of printers, and was codified by lexicographers and grammarians" (3).

To counter this assumption, Fisher (1996:9) asserts that "language is standardized by government and business, rather than by literary usage." He maintains that the "habitual usages" of Chancery clerks taking dictation from a master "created a 'standard."' He offers as evidence the example of the letters of Henry V, which were produced by different clerks but which all "employ the same style, syntax, and orthography." Fisher (1996:11) explains:

The language that had originated with the authority of King Henry V and the Chancery clerks continued to develop under the aegis of writers and scholars who were important government officials. Language was standardized by wide and habitual usage-i.e., by clerks and then printers-but these people worked under the supervision of the dictators, or rulers, who were at the same time the premier authors and educators.

Salmon (1999:15) comments that around 1430, almost a decade after the death of Henry V, "the scribes of the Royal Chancery in Westminster began to send out official 
documents in English nation-wide, thus providing a form of standard orthography which could, and to a large extent did, become a model for imitation throughout the kingdom."

Richardson (1980:726) points to the early 1430s as the time by which "the Chancery had developed a distinctive language, a coherent, standardized written dialect which in its linguistic forms closely resembles modern Standard English.” Richardson explains the theory regarding Chancery English:

Bolstered and sustained by the prestige and authority of any documents issued by the Chancery, by the need for a standardized form of English among lawyers, government officials, legal scribes, and the eternally litigious English gentry, and by the increasing patriotic and practical goodwill toward the formerly despised vernacular, Chancery English slowly spread throughout England during the middle years of the fifteenth century to the point where it became the most commonly accepted written dialect and, in turn, the ancestor of modern Standard.

So, then, as Fisher (1992:9) has demonstrated, "Standard English as it emerged in the sixteenth century is the reflection of the personal style of King Henry V modulated through the practice of government bureaucracy, the London scribes, and the early printers.” Bragg (2011:98) puts it like this:

The King had set an example; Chancery followed; the printing press reinforced the importance of a common written language. By the end of the fifteenth century, English was the language of the state and equipped to carry messages of state in an increasingly uniform spelling north, south, 
east, and west, its manuscripts and later its books rolling over the old dialects which nevertheless stayed stoutly on the tongue.

By the beginning of the $16^{\text {th }}$ century, it seems that everyone in England had picked up the English language. But it still lacked the prestige formerly held by French and the ongoing reverence of Latin held by the ecclesiastical and scholarly communities. As Knowles (1997:77) points out, "writers routinely apologized for writing in English. They felt that English was a rude, vile, barbarous language." Leith (2003:45) observes that many scholars believed that English was not a suitable language "for serious literature," and that "it could never match the heights achieved by the writers of ancient Rome and Greece" (46). By the end of that century, however, the language's status had risen significantly.

What happened during that period of time that caused such a shift in attitude? While several events contributed to the rise in the status of English, two key movements stand out: the Protestant Reformation and the English Renaissance. McGrath (2002) tells us that the Reformation in England effectively began in 1509 when Henry VIII was crowned the teenage king of England. When he came into power, the ban against scripture in English was still in effect in England, but according to White (2009:100) "the Reformation was in full swing in many parts of Europe.” McGrath (2002:33) explains that in 1407 the archbishop of Canterbury had ruled that it was illegal to translate the Bible into English or any other language, or to read any translated version:

We therefore legislate and ordain that nobody shall from this day forth translate any text of Holy Scripture on his own authority into the English, or any other, language, whether in the form of a book, pamphlet or tract, 
and that any such book, pamphlet or tract, whether composed recently or in the time of John Wycliffe, or in the future, shall not be read in part or in whole, in public or in private.

We have previously discussed the Wycliffite translations and the attempts made by Wycliffe and the Lollards to spread Wycliffe's core beliefs about the authority of the Bible and the right of individuals to read and interpret the scriptures for themselves. Wycliffe's work foreshadows that of other reformers such as Martin Luther, a key figure in Germany, and William Tyndale, an Oxford scholar and Roman Catholic priest who believed in the cause of the Reformation.

Tyndale took up the task of translating the Bible from the original languages into English. This undertaking was extremely risky and obviously illegal at the time, so Tyndale left England for the Continent to avoid problems with the Catholic leaders and to hide from the king's spies, who would arrest anyone with an English Bible, let alone someone trying to produce one! Tyndale found a place to stay where he could work secretly, and he finished his translation of the New Testament within a year or so. According to Knowles (1997), Tyndale produced the first New Testament in English in 1525 and during the 1530s he produced six books of the Old Testament. Tyndale and his sympathizers had them printed, and then they were sold or smuggled into England.

The Roman Catholic Church had prohibited the use of English in local parishes and in educational instruction. Tyndale's efforts to provide the Bible in the vernacular were therefore considered heresy by the Pope and the Church leaders in England. Knowles (1997:72) refers to Tyndale's purposes as "radical," and indeed, his refusal to 
abide by the law in this regard eventually led to his arrest and death (by being burned at the stake in 1536).

Why was the Catholic Church so opposed to an English language Bible? While there were undoubtedly many motivations underlying the Church's position, one key factor seems obvious: the Church did not want to lose its power over the masses of people who depended upon it for support. Bucholz \& Key (2004) demonstrate that the Roman Catholic Church held tremendous power and influence over the populace because of its heavy involvement in the daily lives of the English people (providing jobs, homes, and social activities in addition to moral and spiritual guidance). As long as the people trusted their priests to interpret the Holy Scriptures accurately for them, and followed their dictates and direction, the Roman Catholic Church would maintain its status and its influence in England as well as on the Continent. But the problem with so much power in the hands of mere mortals is that humans are subject to temptation. And, while most parish priests were apparently hard-working, caring, and dutiful pastors, there were some, however, who took advantage of their position by charging parishioners high fees for presiding over certain services or events, or by authorizing the sale of "indulgences, which forgave specified amounts of purgatorial time" (91). In addition, some priests even broke their vows of celibacy or committed other acts of moral failure, such as excessive drinking.

These moral failures were not isolated to members of the clergy. Although the Church received its share of criticism regarding the corruption of some of its highranking officials (as well as some of its low-ranking ones), there was plenty of questionable behavior at the highest levels of the government as well. Probably the most 
infamous of the monarchs (in terms of morality and the breaking of Scriptural mandates) was Henry VIII, who reigned from 1509 to 1547 . His penchant for satisfying the desires of the flesh, combined with his determination to produce a male heir, resulted in six marriages. Two of the six ended in divorce/annulment, and three ended in the death of the wife (two were beheaded per Henry's wishes). Only his last wife, Katharine Parr, lived longer than her husband.

But it was the ending of Henry's first marriage that may have inadvertently altered the English language's path to prestige. Because Henry was a lifelong Catholic, he knew that the only way he could marry a new wife (with the current one still living) was to receive an annulment of the first marriage from the pope, the ultimate head of the Church. When the pope refused to grant the annulment, Henry tried to enlist the help of the Parliament. Bucholz \& Key (2004:74) report that when this attempt failed, Henry plotted with the help of his first minister, Thomas Cromwell, to become "the head of the Church in England in the same way that he was head of State." Therefore, Henry could grant his own annulment and proceed with his marriage to his then-pregnant mistress, Anne Boleyn. The king's new status (and the power that came with it) was officially established when Parliament passed the Act of Supremacy in 1534. Not only had Henry released himself from the pope's control in matters of religion, but he had essentially proclaimed that he was the only sovereign power in the land.

White (2009:111) reports that

[i]n 1534, the year after Henry wed Anne Boleyn, there was a meeting of officials in the Church of England called the Convocation of Canterbury. The Convocation petitioned King Henry to issue an official, legal Bible in 
the English language. It had proved impossible to stop Tyndale's New Testament, and the whole matter was becoming an embarrassment to the government and to the clergy, too.

This proposal was approved, but in order to let some of the uproar from the recent religious commotion die down, the members of the Convocation agreed to wait for a new Bible to be produced. This new English translation of the Bible, which was sanctioned by King Henry VIII in 1535, was the Coverdale Bible. This Bible was followed by several others in fairly rapid succession, and according to White (2009:115), all of them "made use of William Tyndale's translation." After the Coverdale Bible came the TyndaleMathew Bible (1537), the Great Bible (1540), the Geneva Bible (1560), the Bishops' Bible (1568), and about fourteen years later, during the reign of Queen Elizabeth I, came the Rheims Bible (1582), a Catholic translation of the Vulgate, in which the original Latin or Greek was retained in certain parts in order to maintain what was understood to be the intended meaning of the text.

Over the next few decades, politics and religion butted heads several more times, but 22 years after Tyndale's death, England was still being led by a member of the Tudor family: Queen Elizabeth I (the daughter of Anne Boleyn, Henry VIII's second wife). She had succeeded her sister Mary (also known as "Bloody Mary" and the daughter of Catherine of Aragon, Henry VIII's first wife). Mary had become the reigning monarch upon the death of her half-brother, Edward VI (his mother was Jane Seymour). Edward VI had ruled England from 1547-53. Bucholz \& Key (2004) record that while King Edward VI had been a devout Protestant, Queen Mary was an extremely committed Catholic. Elizabeth I, anxious to please her subjects and earn their loyalty, pursued a 
position of compromise. Jeffcoat (2002) tells us that under the leadership of the new queen, the Anglican Church agreed to permit English language Bibles, but the Church of Rome insisted on a Catholic version, and thus produced the Rheims New Testament, later adding the Old Testament (called the Douay/Rheims Bible). Knowles (1997:77) comments that other events during the Elizabethan era, such as military victories, the colonization of the "New World," the work of William Shakespeare, the Restoration of the monarchy, and the establishment of English as "the national language of England" played important roles in establishing peace and a sense of national pride, while giving the status of English a boost.

At the same time, according to McLaughlin (1970:55), another "external force which shaped our language—-the English Renaissance" was taking place. As interest in learning and literacy abounded during this period, many people who had not previously had the opportunity for formal education began to demand English translations of the classics. This resulted in an expansion of the lexicon through the borrowing of words from Latin, Greek, French, Italian, and Spanish. As writers incorporated new "English" words into their texts, however, scholars began to notice several problems: inconsistent spelling of words and structure of texts, and many unfamiliar terms. Soon, various "experts" proposed solutions for these textual problems.

McLaughlin (1970:69) notes that Richard Mulcaster's $16^{\text {th }}$ century publication, Elementarie, "was one of the most reasonable attempts to bring some order to English spelling practice" by discussing and outlining rules for the spelling of English words, which had for many years, according to Knowles (1997:61), been subject to the whims of “printing houses" or as McLaughlin (1970:69) remarks, the pronunciation styles of 
individual writers, who "tended to write as they spoke." Many other publications during the Renaissance period influenced the development of "an English standard in speech and writing” (73). Dictionaries such as Robert Cawdrey's Table Alphabeticall of Hard Words and others were created to deal with the spelling issue and to explain in English the many confusing words that had been "borrowed" from Latin and other languages (73).

As a matter of fact, Millward (1996:236) observes that part of the expanded title of Cawdrey's dictionary addressed the need to help "Ladies, Gentlewomen, or any other unskilfull persons. Whereby they may the more easily and better understand many hard English wordes, which they shall heare or read in Scriptures, Sermons, or elsewhere, and also be made able to use the same aptly themselues." This explanation is a careful reminder that English-to-English dictionaries were needed by individuals who had not been schooled and therefore could not read or understand scholarly materials containing Latinate vocabulary. Millward (1996) further notes that prior to Cawdrey’s "monolingual" dictionary (which was published in 1604), readers or travelers often utilized bilingual (or tri-lingual) word lists, such as Latin-Old English, Latin-English, French-English, or Latin-French-English, and so on.

Millward (1996:236) comments that while Cawdrey's dictionary was comprised of "about 2500 rare and borrowed words with definitions in English," subsequent efforts by other producers included more entries, and did not always confine themselves to "hard words." A notable example is Nathaniel Bailey's work, which not only listed 48,000 entries consisting of "ordinary words, etymologies, and cognate forms," but also included “the stress placement of words," which no previous dictionary had done (240). Bailey's 
dictionary was known as the "standard reference" prior to the publication of Samuel Johnson's two-volume A Dictionary of the English Language in 1755.

Johnson concurred with other leading scholars of his time in believing that the English language was in dire need of refinement, re-ordering, and stabilization. This belief became the driving force behind the dictionary that would take him seven years to produce. Ironically, as McLaughlin (1970:77) points out, during the process of trying to "fix" the language; i.e., to "inhibit change,"--not to repair it (although some scholars may prefer the latter definition), Johnson realized that his efforts to 'embalm his language and secure it from corruption and decay' had been in vain. His dictionary, however, did "embalm" the spellings of most of its 40,000 entries, and it became, for its age, the ultimate "authority on the meaning and use of words" (83).

The other area of the language in need of "fixing" (this time it means "repair") was the grammar. As mentioned previously, the inconsistent structure of texts that had, in many cases, been translated from Latin or other languages, led scholars such as Ben Jonson and others to produce written guidebooks (often called "grammars") for the proper use of the English language. After all, the Classical languages of Latin and Greek are full of rules and regulations regarding their use. McLaughlin (1970:68) comments that "[if] English was to take its place beside these eminent languages as a noble vehicle for noble thoughts, it too must have principles governing writing and speaking to guide those who would use it to their best advantage." It was only natural for scholars, wellversed in Latin and Greek, to desire to influence a higher level of prestige on their English tongue. Perhaps they assumed that by creating a grammar of English, they could effectively alter the future path of the language, by developing a society both at home and 
abroad whose members (reasonable people desirous of power, influence, or prestige) would gladly adopt the conventions outlined in the grammar text.

These conventions not only included points of grammar, however. According to McLaughlin (1970:72), Jonson's The English Grammar (which was produced 58 years after Mulcaster's Elementarie) dealt with phonology, accent, and word formation in addition to grammatical issues such as parts of speech (patterned after those of Latin). He continued his efforts in The Second Book of the English Grammar, which focused on syntax and punctuation rules.

One might assume that the publication and distribution of grammar books and dictionaries would take care of the issues concerning the scholars and educators of the seventeenth and eighteenth centuries. However, as is often the case even today, one supposed solution leads to another problem, and so on. McLaughlin (1970:80) tells us that the problem that arose was that within the circles of the authorities-grammarians who created the textbooks in question-were differences of opinion in regard to the approach that should be taken in textbooks which would, ultimately, provide a resource (a guidebook, if you will) for many would-be pupils. Many $17^{\text {th }}$ and $18^{\text {th }}$ century scholars held that the language was corrupt, due to many influences over the centuries, and that it would continue to deteriorate unless some authority could establish specific rules governing language use. Other scholars believed that these "grammars" should "record the facts of language usage, and nothing more."

McLaughlin (1970:80) details how other countries, such as France and Italy, had established "academies" to regulate and maintain the 'purity' of their language. British scholars Jonathan Swift and Daniel Defoe proposed a similar solution for England. Their 
proposals succeeded in stirring up significant controversy and discussion, but an English Academy never materialized. Some writers attribute this failure to politics and to "influential men of good sense who deplored [the idea]" (82), although the death in 1714 of Queen Anne, who had supported the project, likely ended any chance that this "society" would come to fruition. (Anne's successor was George I of Hanover, Germany, the great-grandson of King James I.) Instead, the debate led to increased interest in publishing a text that could do for English grammar what Johnson's dictionary had done for English words; i.e., create an authoritative written text that could be consulted as needed, rather than depending on the regulations of whatever learned men might have formed the proposed academy.

McLaughlin (1970:84) comments that the production of a variety of grammars toward the end of the eighteenth century seemed to have satisfied the need for a written set of rules regarding the "proper use of the language." The prescriptive attitudes of most of these and subsequent grammar texts, with their focus on correctness and propriety, therefore, became the backdrop for the pedagogical approach adopted and used by scores of teachers in Britain and North America for at least the next century.

A discussion of this approach and its influence on the teaching of English grammar to the present day will be undertaken in subsequent chapters. 


\section{CHAPTER III IDEOLOGIES BEHIND ENGLISH GRAMMAR "RULES”}

The previous chapter concluded with a brief mention of the pedagogical approach that was adopted by teachers of English during the eighteenth and nineteenth centuries and is still in vogue in many U.S. schools today. This chapter will discuss some of the ideologies that were common during the eighteenth century among educated people such as the grammarians and scholars whose writings were transformed into grammar 'rules' that represent the ideals of grammatical correctness often labeled "Standard English." Perhaps by examining the historical record we may glean some insight into the rationale behind what we typically refer to as the "rules" of English grammar.

First, we should define 'ideology' for the purpose at hand. I would like to adopt the definition of "linguistic ideologies" used by Silverstein (1979:193) and Woolard (1998:4): 'sets of beliefs about language articulated by users as a rationalization or justification of perceived language structure and use.' Another “definition more specific to language issues, often called standard language ideology (SLI)," has been provided by Lippi-Green (2007:64), who defines SLI

as a bias toward an abstracted, idealized homogenous spoken language which is imposed and maintained by dominant bloc institutions and which names as its model the written language, but which is drawn primarily from the spoken language of the upper middle class. 
Our discussion begins by taking a look at some of the main 'beliefs about language' common among educated people such as the popular grammarians and scholars of the eighteenth century. We will then explore some of the possible origins as well as the ramifications of these beliefs.

According to Pooley (1959:260), "the prevailing conceptions of language" in the eighteenth century "were (1) that language is a divine institution, originally perfect, but debased by man; [and] (2) that English is a corrupt and degenerate off-spring of Latin and Greek." Hickey (2010:3) explains that "[b]efore the eighteenth century studies of the English language frequently displayed a distinctly religious bias." According to Hickey $(2010: 3-4)$

...before the advent of modern linguistics in the nineteenth century, much 'linguistic' work was produced in the belief that all languages can be traced to Hebrew, the language of the Old Testament, via Classical Greek, the language of the New Testament. Latin took its place after Greek and the result was a triad of classical languages which were continually referred to. For instance, in Robert Robinson's The Art of Pronunciation (1617) there is no mention of the social aspects of pronunciation but in the preface there are references to the derivation of words from Hebrew, Greek and Latin and many grateful references to God from whom speech comes.

These two beliefs form a backdrop for the language ideologies that inspired the creation of grammars of the vernacular. During the sixteenth and seventeenth centuries, the idea that 'English is a corrupt and degenerate off-spring of Latin and Greek' was a 
source of much anxiety to scholars. Finegan (1980:19) comments that "British writers justly feared that, as the fluid and multi-dialectal English replaced Latin, chaos and instability could destroy the relative ease of clear and exact communication afforded by the stable classical language in university scholarly use throughout Europe." Apparently these fears were widespread, for as English "came to function where Latin had been used before," many "learned people" expressed concerns that "the new linguistic richness could lead to ineloquent, imprecise, and ambiguous communication.” Finegan (1980:19) points out that “an Englishman named William Bullokar remarked on the 'unruled' state of the English language and called for the creation of a dictionary and grammar." Instead of waiting for someone to take up the cause, however, in 1586 Bullokar "published his own Bref Grammar, the first analysis of English now known."

This text was followed in 1594 by Paul Greaves' publication of Grammatica Anglicana, "an English grammar in Latin" written for the benefit of "foreign as well as British scholars." Finegan reports that Greaves "accused Englishmen of speaking their own tongue ungrammatically." Almost 50 years went by before Ben Jonson's English Grammar (1640) and John Wallis's Grammatica Linguae Anglicanae (1653) came out, in response to an apparent increase in interest in the grammar of the vernacular.

The next 150 years would draw even more attention to the 'ungrammatical[ity]' of the English tongue. In fact, some of the most well-known scholars of the late seventeenth century: John Dryden, Daniel Defoe, and Jonathan Swift, among others, proposed that England needed what France and Italy had already established, an "academy" that could establish and enforce rules for the English language and make decisions on future questions or disagreements in areas of usage and grammar. 
As the previous chapter indicates, the academy was never established, for reasons that are not altogether clear. But as it turned out, perhaps the lack of an English academy was for the best. Finegan (1980:21) alludes to the possibility that "an unofficial academy in the guise of private dictionaries and grammars" had filled the need for an authority over the language. Finegan (1980:23) also comments that Samuel Johnson, who published A Dictionary of the English Language (1755), had "recognized that in the absence of an academy (which he had opposed) the task of ascertaining the language would fall to independent grammarians and lexicographers." Johnson became one of those lexicographers, and, in fact, was likely the most famous lexicographer of the eighteenth century.

Others seemed to place his work in high regard, even saying that Johnson's Dictionary had accomplished what the proposed academy would have been charged with doing. Baugh \& Cable (2002:258) quote Sheridan (1756) as saying: 'if our language should ever be fixed, he [Johnson] must be considered by all posterity as the founder, and his dictionary as the corner stone.' Baugh \& Cable (2002:257) also repeat a comment that appeared in the Journal Britannique (1755): "A notice that appeared on the continent observes that Johnson may boast of being in a way an academy for his island.” In addition, it was noted by Baugh \& Cable (2002:258) that "Boswell was apparently expressing the opinion of his age when he spoke of Johnson as 'the man who had conferred stability on the language of his country'."

If we acknowledge the opinions of the above, and accept that Johnson had 'stabili[zed]' the vocabulary and the spelling of English with his Dictionary, we must also accept that as representatives of the 'independent grammarians' that Johnson alluded 
to, Robert Lowth (1710-1787), Joseph Priestley (1733-1804) and countless other grammarians of the eighteenth century had "attempted [to do the same] for the syntax [and morphology] ..." by way of their respective grammar texts.

Their efforts resulted in an abundance of grammar texts that would preside over English language instruction for the centuries to come. According to Martin \& Rulon (1973:43), overall "[t]hese grammar books were highly prescriptive in tone..." in most cases "prescribing what the language ought to be rather than describing what it is; hence the eighteenth century is often called the Age of Prescriptivism." As Martin \& Rulon (1973:43) describe, these "highly prescriptive school grammars," which contained "countless exercises in which students picked the correct answer according to a set of 'rules' they had memorized," were designed "to modify linguistic behavior with what we now regard as a false set of assumptions" about language:

(a) language should be logical;

(b) change is a sign of decay;

(c) language can be legislated;

(d) speech should imitate writing;

(e) a standard exists which can be defined; [and] finally,

(f) the ability to label parts of the sentence enables the speaker to use ‘better’ English.

The first assumption is that 'language should be logical.' Martin \& Rulon (1973:43) continue their discussion of the grammar texts of the eighteenth century by telling us that "[t]hese and other books give rise to American 'school grammar,' often called TRADITIONAL GRAMMAR, in which English is studied as if it were structured like 
Latin, which was considered a more logical, less corruptible language.” Following Hebrew and Greek, as mentioned above, Latin had long stood as the written standard. Due to its longevity and its widespread use among scholars across Europe, it held a position of prestige that English had not yet achieved.

Additionally, McKay and colleagues (1987:581-582) remind us that the scientific revolution of the 1600s had spurred many intellectual minds toward a primary goal of the "[e]xpansion of knowledge" by the power of "reason" and rational thought. We should also recall that scholars of the eighteenth century were educated in the classical tradition and therefore would have been trained in the liberal arts, also known as the trivium (logic, grammar, and rhetoric), and the quadrivium (arithmetic, music, geometry, and astronomy). Joseph (2002:6) regards the trivium in a liberal arts education as "the organon, or instrument, of all education at all levels because the arts of logic, grammar, and rhetoric are the arts of communication itself in that they govern the means of communication—namely, reading, writing, speaking, and listening."

It makes sense, then, that scholars of this era would have so highly rated logic as a component of language. But what about the next assumption, that 'change is a sign of decay'?

Moore (1970:1-2) remarks that "Latin had ceased in the sixth century to be a living tongue," but "it continued to be used throughout western Europe as the language of the Church and the medium of international intercourse among the educated classes. In this way it enjoyed a kind of after-life that lasted till the Renascence [sic]." Moore also points out that " $[\mathrm{u}] \mathrm{ntil}$ the Renascence [sic] the vernaculars were more or less looked down on by men of learning as irregular, corrupt, and meagre in vocabulary." 
But as Bragg (2011:112) explains, the scientific revolution and the Renaissance had inspired an influx of new vocabulary for the scientific and medical communities, and at the same time the expansion of trade with other countries led to "imported words" as "English ships [sailed] all over the world, trading in goods, looting language." Bragg describes how "English artists, scholars and aristocrats began to explore Europe... and brought back words which described what they saw." The rate at which words were pouring into the English lexicon created anxiety for many individuals who believed that changes in the language could lead to its defilement and decay. According to Bragg (2011:118), Sir John Cheke (1514-57), Provost of King's College, Cambridge, "argued strongly that English should not be polluted by other tongues."

But according to Graddol and colleagues (1996:158), the desire for linguistic order did not arise simply from a desire to emulate the classical languages. Writers like Swift were anxious to preserve the political order with which they identified. For these writers the fixing of the language was to help safeguard what Swift called the "civil or religious constitution'.

Apparently Swift was concerned because during the English Civil War in the midseventeenth century, there had been some confusion over terms, which philosopher Thomas Hobbes referred to as "a 'breakdown' of language." Hobbes worried that "[i]f language was breaking down...it was a sure sign that society too was breaking down." Graddol and colleagues (1996:158) note further that "[t]hese kinds of association between the condition of the language, the political constitution (or state) and the issue of social cohesion have endured in Britain ever since." 
Steps had to be taken to ensure that English society would not 'break down' any further, and the belief that 'language can be legislated' inspired some of the leading scholars to action. Thus, Blank (2008:212) notes, "[t]he early modern period in England saw the first systematic attempts to create, or recreate, a universal language, a 'perfect' tongue." This "common language," it was hoped, would stem the anxiety about the decay of the language brought about by the "influx of foreign words and a habit of creating new English words out of foreign elements..." Blank (2008:237) writes that a group called the "Royal Society" had "sponsored the project of creating a universal language, for all nations, that would clear up" the linguistic confusion (often referred to as 'Babel') that abounded in early modern England. However, despite many attempts, a "universal language" was never established, but the diversity of dialects and the vast increase in the vocabulary of the vernacular during that era did inspire many scholars to write glossaries and dictionaries of "hard words" for individuals who wanted to advance their knowledge and to help foreigners increase their understanding of English.

By the eighteenth century, according to Hook \& Mathews (1959:107), some grammarians, failing to recognize the inevitability of linguistic change, strove to stop or at least retard it. They believed that change in a language is undesirable; since Latin was the most highly regarded language, and since Latin had not changed much in fifteen hundred years or so, change must be bad.

The changes that English had endured throughout the years leading up to the eighteenth century, and the upheaval in society that had resulted due to the diversity of dialects, the infusion of foreign terms, and the revival and adaptation of older forms were 
sufficient to cause many influential scholars and leaders to urge the creation of a language academy that Tieken-Boon van Ostade (2008a:241) reports "would codify the language by refining and fixing it, and by laying down its rules in an authoritative grammar and dictionary." Language academies had been founded in Italy (1582) and in France (1635), as Finegan (1998:538) points out, "for the cultivation and regulation of their vernacular..." England had its "Royal Society," which had been in existence since the 1660s, and although its main interests were in the field of science, this group had "[f]rom its early days...concerned itself with matters of language, setting up a committee in 1664 whose principal aim was to encourage the members of the Royal Society to use appropriate and correct language."

It is interesting to note that many attempts have been made throughout history to legislate language. Ostler (2007:168) discusses a proposal by Alcuin of York, who in the late eighth century pushed for all speakers of Latin to use the same "new, universal style of pronunciation for Latin, deliberately reconstructed [by Alcuin himself] to be close to its original sound." While the concept of "a single norm" might seem to make sense, it simply was not immediately practical, as it apparently created problems for all concerned. Priests could no longer be understood by parishioners who had previously been able to follow their sermons, unless they had studied the new "foreign language" version of Latin. Finally, in order to ensure comprehension, the Church authorities ruled that priests should deliver their messages in the vernacular of their regions.

It is evident that attempts to regulate language use often come from religious leaders or scholarly institutions, but many times these leaders work in conjunction with authorities from the highest office in the land. Hollis (2012:2) reports that in the late ninth 
century, for example, King Alfred "called for the teaching of vernacular literacy to all young persons... of the freeborn classes and the subsequent teaching of Latin to the more promising of them..." Law (1987:48) notes that Alfred "realized the importance of translations of the fundamental Latin texts for religious purposes, and instituted a programme of systematic translation, an initiative that was revived two generations later with the Benedictine reform movement.” Unfortunately, as Law comments, “...in spite of this early evidence of engagement with the problems of translation, there is little sign of linguistic introspection. Anglo-Saxon grammarians focused their attention upon Latin."

Still, there is evidence that the process of standardization was underway, even if only as a byproduct of other work. Greenfield \& Calder (1986:63) point out that the vernacular prose writings that were produced as a result of Alfred's influence have "been used to establish Early West Saxon as ‘standard Old English’ for many an English grammar”; however, “...many linguists prefer Ælfric’s language (Late West Saxon) as the norm for the study of the language." As Fulk \& Cain (2003:161) remind us, "It was Elfric who produced the first vernacular grammar of Latin, Excerptiones de arte grammaticae anglice.” Greenfield \& Calder (1986:69) have suggested that Æthelwold, one of the most prominent figures in the Benedictine revival and the English monk under whom Ælfric had studied at Winchester, so greatly influenced "the development of Old English prose" that he may be responsible for having "established West Saxon as the standard literary dialect." It must be pointed out, however, that some scholars, including Hogg (2009:400-401) question the label "Standard Old English."

Whether or not Late West Saxon can be called the 'standard' language of its era, there have been many other attempts to legislate language over the centuries. Another 
example took place after the Norman Conquest of Britain in 1066, when the newly established ruler, William I (also known as William the Conqueror, Duke of Normandy), appointed Frenchmen to positions of power in the government and in the Church. Millward (1996:142) notes that "[e]ven the scriptoria of the monasteries were taken over by French speakers..." Naturally, the new leader of the country would replace the old aristocracy with his trusted friends and followers, people who shared his language, his culture, and his way of thinking. This action effectively changed the "official" language of the country to French.

For the next three hundred years the language of the law courts, the government, and the literature produced through official channels was French, and as Moore (1970:27) points out, "English ceased to be heard among the educated classes." The British peasants and the servants of those in power, however, still spoke various dialects of English. In fact, many of the French speakers in charge picked up some English due to intermarriage as well as to necessity. They had to be able to communicate with their Anglo-Saxon housekeepers, caretakers, and child care workers. So, during the three centuries of French control of England, the number of English speakers actually grew instead of diminishing. Another attempt to legislate language (actually the study of language) occurred during the reign of King Henry VIII, who in 1542 established William Lily's A Short Introduction of Grammar... (1540) as "the official" grammar of England, even though as Jones (1953:278) points out, it was “written in Latin.” Jones (1953:279) reports that later editions of Lily's grammar "were entirely rendered in English and had been reinforced by supplementary and auxiliary works, all in English. The vernacular had become the medium through which Latin was to be taught." 
There have been other attempts to legislate language as well. In the more recent past, for example, Lippi-Green (2007:131) documents a variety of cases in which educators and administrators have tried (and many times succeeded) to establish language policies related to the use of "that mythical perfect spoken language we call Standard English.”

Next, the assumption that 'speech should imitate writing' is a reference to imitatio, or imitation, which Burton (Web) describes as "a fundamental method of instruction in ancient Roman and in Renaissance humanist curricula..." This strategy of teaching

took place on many levels and through many methods. At an elementary level students used imitation in learning the rudiments of Greek or Latin (spelling, grammar), copying the purity of speech of a given author. As they progressed, they were taught parsing (finding the parts of speech), which led to various kinds of rhetorical analysis of their models (finding figures of speech, argumentative strategies, patterns of arrangement). Students were instructed to use copybooks to record passages from their reading that exemplified noteworthy content or form, which they would then quote or imitate within their own speeches or compositions.

This method of instruction seems to follow "the pattern for grammar studies" set by a work written by Dionysus Thrax (100 B.C.) called Techne Grammatike. Martin \& Rulon (1973:41) quote from the preface Thrax's belief "that grammar is the practical knowledge of the written language of poets and prose writers and that the study of 
grammar should be undertaken to help the student read aloud, understand, and appreciate the literary works of those writers."

Mulroy (2003:36) shares that "[a]s a practical discipline, grammar has two, closely related goals. It preserves and perfects understanding of the great literature of the past, and it contributes to eloquent self-expression." He adds that "the utility of grammar in preserving the appreciation of the old classics and fostering new eloquence is also one of the great lessons of the European Renaissance."

At the end of the seventeenth century there was great concern that if the language continued to change, in a few hundred years it might be difficult or impossible for readers to understand the written words of their popular essayists, such as John Dryden. Krutch (1969:112) comments that "Alexander Pope was still sufficiently suspicious of the stability of his own language to write, 'For such as Chaucer is shall Dryden be'."

This comment was an allusion to the writing of Geoffrey Chaucer, who had died in 1400 — only three centuries earlier. If the language had changed that much in such a short period of time, what guarantee did writers such as Dryden have that their writing would be understood by future readers?

These 'lessons' about the goals of grammar merge with the perceived goals of grammar-writers of the eighteenth century, who used lines from 'the great literature of the past' as examples for their observations and instruction on points of grammar and usage. Grammar texts reflected their belief that 'a standard exists which can be defined,' and this standard represented, according to Baugh \& Cable (2002:277), a coherent prescriptive tradition, within which eighteenth century grammarians aimed to do three things: (1) to codify the principles of the 
language and reduce it to rule; (2) to settle disputed points and decide cases of divided usage; and (3) to point out common errors or what were supposed to be errors, and thus correct and improve the language.

The belief that 'a standard exists' is actually separate from 'which can be defined.' As has been previously discussed, there had been three highly idealized languages: Latin, Greek, and Hebrew. Jones (1953) and others may be consulted for the history of these languages and their perceived appeal. 'Standard' actually referred to "standard of correctness in language," but the definition of this was exemplified by the characteristics of the classical languages which were so highly esteemed. Scholars held that Latin, Greek, and Hebrew had proven themselves in purity, elegance, and stability over time. Jones (1953:234) refers to 'purity' as "native purity" as in the original form of the language, without additions such as borrowed words from other languages. Jones (1953:13) describes 'elegance' as having “literary qualities," 'eloquence,' or polished, graceful phrasing. Baugh \& Cable (2002:255) indicate that 'stability' in language refers to "a strong sense of order" and "regularity" in a permanent, unchanging form. In order to establish a 'standard' authoritative form of English, it would be necessary to select the dialect of England which seemed closest to these ideals. It would then be possible to establish a set of rules for English, rules that could help the grammarians achieve their aims: "to prescribe and to proscribe" (262).

The dialect that was destined to become the 'standard' had been chosen, actually, during the latter part of the fifteenth century. Millward (1996:224) reflects on the fact that when William Caxton set up his first printing press in Westminster (near the London area), naturally "the written English of the texts produced was in the London dialect, a 
fact important in making this dialect the standard for written English throughout England." Printing was a key factor in the standardization process in several ways. Millward (1996:224) says that printing "was heavily responsible for freezing English spelling." (This happened "just before a major sound change was completed," which explains why many English words are spelled differently from the way they are pronounced.) Millward also attributes the increased interest in literacy and the desire for books to the advent of printing. Books and other printed materials circulated around England, spreading the London dialect far from the city limits, into regions in which other dialects of English were spoken.

But the idea that the London dialect became the standard (by default) because of the proximity of Caxton's printing shop to the center of commerce, government, and the Royal Court has been challenged by Fisher (1996). The 'standard,' according to Fisher (1996:2) emerged as a process involving "government bureaucrats, men of letters, teachers, and publishers who have inherited from Henry V and the English Chancery of the fifteenth century." Fisher discusses the fact that "[b]y the end of the fifteenth century, printers and educators began to assume dominant roles in codifying the approved forms and idioms of written English, just as educators had for centuries controlled the approved forms and idioms of Latin." Before Caxton had brought his printing press to England, and "before English became part of the educational establishment," Fisher (1996:64) continues,

English first began to be used regularly for government, business, and private transactions. The essential characteristics of Modern written English were determined by the practice of the clerks in Chancery and 
communicated throughout England by professional scribes writing in Chancery script and under the influence of Chancery idiom.

However, even though Caxton "printed in a language strongly influenced by Chancery standard..." which was "the normal language for all official [governmental] communications," Fisher (1996:64) points out that "within a few years printers were introducing are for Chancery be/ben (found in London documents before 1420) and $s$ for Chancery third-person th (found in London documents by the 1450s)."

The 'standard,' then, that we find emerging in the eighteenth century was the result of many influences. What remained for the grammar-writers of that era was to codify the 'rules' which would exemplify this model of English. In A Proposal for correcting, improving and ascertaining the English tongue, a letter to the Earl of Oxford, Jonathan Swift (1712) had clearly stated the problems with the language:

...My LORD, I do here, in the Name of all the Learned and Polite Persons of the Nation, complain to Your LORDSHIP, as First Minister, that our Language is extremely imperfect; that its daily Improvements are by no means in proportion to its daily Corruptions; that the Pretenders to polish and refine it, have chiefly multiplied Abuses and Absurdities; and, that in many Instances, it offends against every part of Grammar...

We should also note that the lexicographer we discussed earlier, Samuel Johnson, had commented on problems with the language in the preface to his Dictionary, which McAdam \& Milne (1964:4) highlight in their publication:

When I took the first survey of my undertaking, I found our speech copious without order, and energetick without rules; wherever I turned my 
view, there was perplexity to be disentangled, and confusion to be regulated; choice was to be made out of boundless variety, without any established principle of selection; adulterations were to be detected, without a settled test of purity; and modes of expression to be rejected or received, without the suffrages of any writers of classical reputation or acknowledged authority.

Thus, it seems that the scholars of the period had their work cut out for them (if I may use one of our American English idioms). Many grammar-writers responded to Swift's complaint by creating a list of observations about grammar or usage deemed to be "correct." One of these grammar-writers was Robert Lowth, the university professor/grammarian/bishop who, according to Tieken-Boon Van Ostade (2011:1) now "has the status of an icon of prescriptivism." In the preface to his A Short Introduction to English Grammar, Lowth (1967 [1762]:v-vi) addresses Swift's remonstrance by saying in effect, that the 'imperfect[ions],' 'Corruptions,' 'Abuses and Absurdities' that Swift sees in 'Our Language' are not the fault of "the language [itself], but the practice..." Lowth (1967[1762]:vi) goes on to say:

The truth is, grammar is very much neglected among us; and it is not the difficulty of the language, but on the contrary the simplicity and facility of it, that occasions this neglect. Were the language less easy and simple, we should find ourselves under a necessity of studying it with more care and attention. But as it is, we take it for granted, that we have a competent knowledge and skill, and are able to acquit ourselves properly, in our own native tongue; a faculty, solely acquired by use, conducted by habit, and 
tried by the ear, carries us on without reflection; we meet with no rubs or difficulties in our way, or we do not perceive them; we find ourselves able to go on without rules, and we do not so much as suspect, that we stand in need of them.

However, as the preface continues, we read that Lowth (1967[1762]:vii) has observed some "gross mistakes" in the writing of some of the "best authors" of the day, and he believes that it may be helpful to offer those as examples in his text so that readers may "evince the necessity of the study of grammar in our own language; and to admonish those, who set up for authors among us, that they would do well to consider this part of learning as an object not altogether beneath their regard." It seems that Lowth believed that even professional writers need a little review of grammar from time to time!

Lowth (1967[1762]:vii) even acknowledges that, while "[t]he construction of this language is so easy and obvious, that our grammarians have thought it hardly worth while to give us any thing like a regular and systematical syntax," it might not be a bad idea to be clear about what the rules are, and to offer some recognizable passages as examples to illustrate the rules. His explanation appears as follows:

The principal design of a grammar of any language is to teach us to express ourselves with propriety in that language; and to enable us to judge of every phrase and form of construction, whether it be right or not. The plain way of doing this is, to lay down rules, and to illustrate them by examples. But, besides shewing what is right, the matter may be further explained by pointing out what is wrong. I will not take upon me to say, whether we have any Grammar that sufficiently instructs us by rule and 
example; but I am sure we have none, that in the manner here attempted, teaches us what is right, by shewing what is wrong; though this perhaps may prove the more useful and effectual method of instruction.

In this passage, Lowth seems concerned about what we in the current day refer to as "best practices" in our teaching. It seems like a fitting connection to the next (and final) assumption about language held by the eighteenth-century grammarians and many of the educators that followed in their prescriptive footsteps: the idea that 'the ability to label parts of the sentence enables the speaker to use 'better' English.'

This is an interesting concept, indeed. First, the 'ability' that is being referred to above is known as parsing. According to Brown \& Kiddle $(1855,2008: 33)$, "[p]arsing is the resolving or explaining of a sentence according to the definitions and rules of grammar." In the original preface to his grammar, Brown offers the following opinion regarding 'best practices' in the teaching of grammar:

The only successful method of teaching grammar, is, to cause the principal definitions and rules to be committed thoroughly to memory that they may ever afterward be readily applied. And the pupil should be alternately exercised in learning small portions of his book, and then applying them in parsing, till the whole is rendered familiar.

Daniel (1901:4-5) offers his explanation of parsing beneath the broad category Parts of Speech. "If we examine the separate words of which sentences are made up, we shall find that they discharge different functions, i.e. are used for different purposes." He then provides four sentences and gives specific analyses to describe the function of each word. The next point in this section (5) says: "Words that discharge the same function in 
a sentence are said to belong to the same part of speech. To parse a word is, primarily, to say to which part of speech it belongs."

The idea, therefore, is that if an individual can identify and distinguish between a noun and an adjective, a preposition and an interjection, he or she should be able to use 'better English.' There must be more to it than this.

And there is. In the introduction to Part I of their important work, Standard English, the widening debate, Bex \& Watts (1999:14) discuss two features of eighteenth century grammars that Watts comments on in Chapter 2, Social construction of Standard English: "their constant references to the classical languages and their concentration on proscription." They go on to say that

[n]ecessarily, a knowledge of Greek and Latin implied a degree of education. By relating the parsing of English with the parsing of Latin, an indirect appeal could be made to the status that accrued to those people who had received a classical education.

So, the simple answer is that eighteenth-century grammarians believed that the ability to parse led to the ability to use the English language better because it did so for Latin. (And you could look down your nose at anyone who had not been educated in the classical tradition.) But anyone who has studied Latin even a little should recognize the fact that parsing a Latin sentence might actually help one to write new Latin sentences, or to construe Latin sentences into English.

But as Buck (1909:23-24) points out, the ability to "analyze a sentence... [and] to discover the parts of speech," followed by learning how to connect words of one part of speech to those of another part of speech, what Buck calls "a mechanical aggregation of 
separate words" does not constitute language. It definitely does not constitute "using better English'.

Buck (25) makes an important point when she says:

The sentences which grammar presents to us have in very truth ceased to be language, once they have been cut off from all reference to the various acts of thought-communication which gave rise to them, so that they seem to exist in and for themselves, mere mechanical congeries of words, brought together only to fulfil certain arbitrary requirements of the sentence form as such.

Earlier in this discussion it was mentioned that the scholars of the eighteenth century 'had their work cut out for them' in terms of codifying the rules of English grammar, and in determining 'the most useful and effective methods of instruction. My hope is that this discussion has brought to light at least a small portion of the rationale for some of the eighteenth-century ideologies about language, and that this knowledge will help us to become better-informed teachers (and students) of English. 


\section{CHAPTER IV}

\section{THE PROBLEM WITH MULTIPLE NEGATION}

The preoccupation with logic during the seventeenth and eighteenth centuries may have led to the decrease in use of certain constructions that had been part of the English language for centuries. One of those constructions involves the use of more than one word to indicate negation. In Present Day English, we typically negate a verb by inserting one word, "not," into the predicate of a sentence; for example, "Mary is not my sister." But this pattern, which we take for granted as the right way to form the negative of a verb, was not always in effect. In fact, it seems that the formulation of negative constructions may have gone full circle from the very beginning of the English language up to today, and we may still be circling.

The purpose of this discussion is to analyze one of the proscriptions that became widespread during the eighteenth century and continues to plague schoolchildren to this day. I include this topic not to argue that multiple negation should be acceptable in Standard English, but as part of my mantra that teachers of English should understand the history behind the rules they are enforcing. By doing so, they may develop a deeper appreciation for the dialects existing today that employ this feature. They may also become better able to present this point of grammar in a useful fashion to their students.

Interestingly, the history of English documents the acceptability of multiple negation from Old English (beginning in roughly A.D. 450) until sometime in the 
seventeenth century (Lynch 2009), although it has been noted by Beal (2004:114) that "double negation was used in informal and lower-class writing and speech throughout the eighteenth century."

Speakers of Old English (dating from roughly A.D. 449 - 1100), initially used one word, "ne," to indicate a negative, as exemplified in Beukema (1999:11): "ic ne secge" meaning "I do not say" or "I say not." Thomas Pyles (1964:205) points out that "ne was frequently joined to a following verb if this began with $h$ or $w$ or with a vowel, for example, Old English nabban 'not to have,' neom 'am not,' nat 'know(s) not,' nyllan 'be unwilling, .' Cheshire (1999:29) indicates, however, following the pattern offered by Jespersen (1917), that this form was “too weak..." [as Beukema (1999:10) points out, “phonologically"] "to survive unaccompanied, and by the Middle English period had been strengthened by the addition of 'not'." The sentence given as an example in Beukema (11) would then have changed to "ic ne seye not."

Cheshire (1999:29) notes that Jespersen's “pattern for the evolution of negative expressions... is sometimes referred to as the Negative Cycle.” Beukema (1999:10) points out that within this 'Negative Cycle' "there is a developmental pattern in systems of sentential negation.” This pattern begins with “"classical' Old English: ne, always preceding the finite verb," as in (a). The next "stage" takes place in "Late Old English and throughout the Middle English period: ne strengthened by not; finite verbs placed between $n e$ and not" as in (b). The next stage, "beginning in the Late Middle English period," and not ending until almost the eighteenth century, involves the eventual elimination of the original negator ne, leaving the "finite verbs placed in front of not" as in (c). During the fifteenth century, there are two options for " "lexical' (i.e. non-auxiliary) 
verbs": the first, seen in (d), in which not precedes the verb, and the second, seen in (e), in which a form of do precedes not in support of the "uninflected lexical verb." The “enclitic form -n't" later develops from not, as seen in (f) (10).

(a) Ic ne secge

(b) I ne seye not

(c) I say not

(d) I not say [+Fin]

(e) I do not say [-Fin]

(f) I don't say [-Fin $]^{2}$

(adapted from Beukema 1999:11)

By examining some of the preserved writings from the Middle English period (approximately A.D. 1100-1500), we can see that the custom was to include additional negators (such as not, nys, no, and others) in a sentence in order to make the negation more emphatic. Writing in the fourteenth century, Geoffrey Chaucer, (Chaucer, Greenblatt \& Adams 2006:255), includes many examples of this feature. For example, in lines 234 to 236 of The Nun's Priest's Tale, we read: “To God that is so just and resonable, That he ne wol nat suffer it heled [concealed] be, Though it abide a yeer or two or three" (italics mine). Later (in line 420) we notice another example of double negation: "But I ne can nat bulte it to the bren," translated as [But I can not] "sift it to the bran, i.e., get to the bottom of it" (259; italics mine). In Chaucer's writing we find not only double negation, but triple and even quadruple negation. In the General Prologue to The Canterbury Tales we read a description of the Friar (line 251): "There nas no man nowher so vertuous:" (176; italics mine), in which three negators are used: (nas, a 
combination of never and was; no; and nowher). We find four negators in an oft-cited passage (lines 70 and 71), in which Chaucer describes the "worthy Knight": "He nevere yit no vilainye ne saide /In al his lif unto no manere wight: /He was a verray, parfit, gentil knight" (172; italics mine), translated by Lerer (2007:75-76) as "He never, to this point, in any way said anything bad in all of his life to any kind of person."

Two centuries later, multiple negatives were apparently still somewhat acceptable, as we can see in the early seventeenth-century plays of William Shakespeare (1975:86). In Act III, Scene I, of Twelfth Night, we find: “And that no woman has; nor never none / Shall mistress be of it, save I alone" (italics mine).

But in Shakespeare's work we notice a mixture of negation patterns. As noted above, in some instances he uses multiple negators, while in others, he uses a construction that seems very modern in comparison. In Act I, Scene II of As You Like It, Celia says, "You know my father hath no child but I, nor none is like to have..." (231; italics mine). A few lines further, she says, "Marry, I pr' ythee, do, to make sport withal: but love no man in good earnest; nor no further in sport neither than with safety of a pure blush thou mayst in honour come off again" (231; italics mine). In these two statements we see the remnants of an earlier style of negation; however, later on, in Act IV, Scene I, we notice Rosalind saying: "The poor world is almost six thousand years old, and in all this time there was not any man died in his own person..." (247; italics mine). If this had been written two centuries earlier, we might expect to read a phrase like ...in all this time there ne nas no man...

The fact that we see a mix of the older and the newer style of negation seems understandable, given what we know about language change. If we take a cursory glance 
through a few lines of a Shakespearean play, and then take a similar view of one of Chaucer's works, we would no doubt notice that while we may not understand all of Shakespeare's terminology, it is by far easier to comprehend his language than that of Chaucer.

Shakespeare's plays were written in the late sixteenth and early seventeenth century, which falls within the Early Modern period (approximately A.D. 1500-1800) of English. Fowler \& Burchfield (1996:227) state that "[a]t some point between the 16c. and the $18 \mathrm{c}$., for reasons no longer discoverable, double negatives became socially unacceptable in standard English.” Perhaps the exact reasons are not 'discoverable,' but from a brief examination of the period we can surmise several factors that may have influenced this change.

As we have previously discussed, by the late fifteenth century, many important events had occurred, and others were underway. Millward (1996:224) points out that the introduction of the printing press to England in 1476 affected the language in many ways: from the freezing of spelling and the "decline in prestige of regional dialects because they were no longer being written down" to the establishment of the London dialect as the "standard" for written material due to the location of the printing press. In addition, wider availability of printed materials led to increased literacy among the middle and lower classes.

Another important event that contributed to changes in the language was the English Renaissance. Millward (1996:225) credits [t]he "revival of interest in classical learning" with many medieval texts previously available only in Latin or Greek being translated into English. Bragg (2011:113) notes that schools teaching "pure and literary 
Latin" were established by scholars at Oxford and Cambridge universities. These "humanists...saw Latin as the language of classical thought, science and philosophy..." and they believed Latin to be "the universal language, with which they could communicate with other European scholars." Despite Latin's previous connection with the Church and the controversies surrounding the rise of English as an acceptable language for religious purposes, the classical language still held prestige and respectability, as did Greek. Bragg points out that words borrowed from Greek and Latin seemed to offer a comforting "[r]eassurance" to English, and put it on par with the "superior" languages of the past, which had "thousands of years of achievement" to their credit.

The influx of vocabulary was not the only benefit of the many translations of classical works into English. Millward (1996:225) comments that the act of translating "also gave English authors practice in developing a sophisticated English style that incorporated the features of classical rhetoric compatible with English" and at the same time "added to the status of the English language." However, this also "forced English writers to compare English to Latin.”

Perhaps we can attempt to connect the dots from the above history to our present concern regarding the acceptability of multiple negation. We know that the study of Latin had been revived due to the efforts of Renaissance scholars, and, as Martin \& Rulon (1973:41-42) discuss, England's William Lily wrote a Latin grammar (1540) “modeled on Donatus and Priscian," the "most influential grammarians for the study of Latin." Lily's grammar received "the official sanction of Henry VIII for use in the schools." As popular as it was to study Latin, it eventually became even more popular to study 
English, as evidenced by the increase in production of grammars of English over the next 250 years.

Martin \& Rulon (1973:42) continue their discussion by saying that four decades after Lily's Latin grammar was printed, William Bullokar (1586) produced " $[\mathrm{t}]$ he first English grammar, entitled Pamphlet for Grammar." After Bullokar's publication came texts "in English and in Latin, describing English in terms of Latin, among them Ben Jonson's The English Grammar (1640) and John Wallis's Grammatica Lingua Anglicanae (1653)...” According to Tieken-Boon van Ostade (2008b:2-4), only four grammars were produced during the fifty years following the production of Bullokar's pamphlet, with fewer than 30 new grammars being produced during the entire period between 1580 and 1740; however, during the subsequent period, from roughly the middle of the eighteenth century through the end of the nineteenth century, approximately one thousand new grammars were published (see Figure 1 and Figure 2).

One of the many new grammars that were published during the eighteenth century was written by Robert Lowth (1762), who wrote A Short Introduction to English Grammar "for his eldest son, Thomas Henry, as a means of facilitating his learning of Latin by the time he would be old enough to enter grammar school" (Tieken-Boon van Ostade 2011:9). Lowth's grammar is frequently blamed for "causing the disappearance from Standard English of the double negative" (3). As Tieken-Boon van Ostade points out, however, the discussion regarding double negatives did not even appear in Lowth's first edition, and it was likely added to the second edition after a reader alerted him to its omission. Further, "Lowth was not the first English grammarian to deal with the 
phenomenon by a long way" (11). Tieken-Boon van Ostade names seven grammarians between 1711 and 1754 whose texts include discussions on double negation.

Tieken-Boon van Ostade further points out that as far as Lowth's "alleged influence on usage," her 1982 publication includes an "analysis of eighteenth-century usage...that shows that double negation was far from common in the language of educated speakers at the time" (11). She cites studies by Nevalainen \& RaumolinBrunberg (2003) and Gonzalez-Diaz (2008) that confirm that constructions such as double negation and double comparatives and superlatives had been decreasing in use during the previous century.

Beal (2004:114) concurs that this "construction seems already to have been disappearing from standard usage" along with double comparatives (such as 'more fairer' or 'more fairest'), which were also labeled by grammarians as "illogical." Denison (1998:243) indicates that “...multiple negation had become vanishingly rare" by the last quarter of the eighteenth century.

If double negation was already "on the way out" of use in Standard English (Tieken-Boon Van Ostade 2009:79), it makes sense that Lowth might not have seen the need to include it in his grammar at first. However, his second edition did include the following description, as cited in Tieken-Boon van Ostade (2011:12):

Two Negatives in English destroy one another, or are equivalent to an Affirmative: as,

'Nor did they not perceive the evil plight

In which they were, or the fierce pains not feel.'

Milton, P.L. i.335. 
In addition, Tieken-Boon van Ostade (12) cites Lowth's footnote examples from Shakespeare and Chaucer to illustrate how double negation was used in the past as compared with the mid-eighteenth century. From Shakespeare's Much Ado about Nothing:

'Give not me counsel,

Nor let no comforter delight mine ear.'

'She cannot love, Nor take no shape nor project of affection.'

(The Chaucer citation included in Lowth's footnote is the description of the 'worthy knight,' which is provided in the earlier discussion of the accepted use of multiple negation during the Middle English period.)

Tieken-Boon van Ostade also points out that Lowth is "merely describe[ing] the effect of the use of two negatives, following what was by then already a common maxim, that two negatives cancel each other out, noting at the same time, in the footnote, that usage had been different in the past" (12).

Whether Lowth intended his comments on negation as prescriptive or descriptive, subsequent grammarians adapted his words to create more prescriptive-sounding rules; in fact, Lindley Murray (1795:121, cited in Tieken-Boon van Ostade 2011:12) writes the rule as follows:

\section{RULE XVI.}

Two negatives, in English, destroy one another, or are equivalent to an affirmative; as, 'Nor did they not perceive him;' that is, 'they did perceive him.' 'Never shall I not confess:' that is, 'I shall never avoid confessing;' 


\section{or, 'I shall always confess.' But it is better to express an affirmation by}

\section{a regular affirmative than by two negatives.}

This is the rule that has been adapted into grammar texts for over 200 years.

It is interesting to note that writers such as Chaucer and Shakespeare had included multiple negation in their writing as it reflected the accepted English usage of their times. As the focus on Latin and scholarly pursuits increased during the English Renaissance, the focus on language and the need to 'fix' it resulted in the creation not of a language academy, as many scholars had urged, but instead, of dictionaries and grammar texts. The goal of these publications, according to Bailey (2010:190), seems to have been concerned with improving the language, with two "themes" of discussion as to how this could be done. One side believed that normative, prescriptive grammars could promote "reason and regularity, that is, grammar as a branch of logic and thought," while the other side “was based on elegance and propriety." Grammars such as Lowth’s and Murray’s have often been described as presenting rules based on logic, such as the supposed mathematical analogy of 'two negatives make a positive' (which is false in the mathematical sense). However, it is the logic of Latin grammar, not algebra, which provided Lowth, Murray, and others with the 'rule.' Students of prescriptive grammars may interpret the use of multiple negatives as illogical, and therefore, not appropriate for those who want to portray themselves as members of an elite social class.

Hickey (2010:17) clarifies for us the connection between eighteenth-century notions of 'elegance' and 'propriety' in language use and one's social status. The term "elegant" was associated with other "positive" terms such as "polite," "refined," and 
“cultivated." Tieken-Boon Van Ostade (2010b:77) comments on "the function of the grammars as linguistic guidebooks for those who wished to rise in society."

Mugglestone (2003:12-13) notes that

grammars, dictionaries, and manuals of linguistic usage of the eighteenth and nineteenth centuries gradually...began to take on important implications for pronunciation too—and for those issues of 'propriety,' and 'impropriety,' 'correctness,' and 'mistake,' which also began to infuse attitudes toward spoken English at this time.

It should have been no surprise, then, Denison (1998:243) notes, that "when [multiple negation] reappeared in the nineteenth century it was a clear literary marker of non-standard usage" which itself was often taken as a sign of a person's social class. Charles Dickens (2012:18) often used multiple negatives in the speech of individuals of 'lower' status in society. For example, in Oliver Twist, first published in 1838, a seedy Mr. Gamfield tries to convince the parish board to let him add Oliver to his team of apprentices by explaining why a little fire in the fireplace is a good way to encourage a young chimney sweep to move quickly: “...that's all smoke and no blaze; veras, smoke ain't o' no use at all in makin a boy come down..." Later, Mr. Bumble, the "gentleman" in charge of the workhouse where Oliver lives, explains the good fortune of the apprenticeship offer to a tearful Oliver: “....and all for a naughty orphan which nobody can't love" (20).

In Present Day English (PDE), using double or multiple negatives in a sentence when one would suffice is often considered "incorrect" (Lunsford et al. 2011:704; Oxford American Dictionary \& Thesaurus 2009:381), or even ‘bad English' (Herndon 
1976:283). This usage is referred to as "nonstandard" or "substandard" and as Skinner (2012:85) describes, is “...verboten in standard English.” It is recognized by some modern grammar writers, however, that "[w]ords and grammatical forms called nonstandard are used by many intelligent people who speak dialects other than standard English" (Fowler \& Aaron 1992:479). According to The Oxford English Grammar (Greenbaum 1996:56), "Non-standard dialects use more than one negative to emphasize the negation," as in the following examples:

(1) * Nobody told me nothing.

(2) * We don't want none, neither.

Grammarian Paul Hopper (1999:180) notes that "[m]ultiple negatives... are commonly heard in the spoken registers in almost all dialects in English..." But in general, writers of grammar texts and usage guides warn writers to "stay away from" (O'Conner 2003:188) or to "avoid" (Hollander 1993:174; Aaron 1995:126) the inclusion of double negatives in constructions such as the above examples.

Warriner (1982:235-236) comments that "[B]efore the eighteenth century, the double negative —or triple negative or quadruple negative — was both useful and popular. The more negatives used in a sentence, the more emphatically the writer or speaker meant 'No!"” His explanation for students of the $20^{\text {th }}$ century: "This piling up of negatives is no longer good English usage. We now express the same idea with only one negative in the sentence..." Further, he urges readers of his grammar text: "Keep your usage up-to-date by avoiding such double negatives..." (236), which he follows with examples of sentences illustrating what he terms "standard" and "nonstandard" usage, such as: 
*Barney does not ever do no work. (Nonstandard)

Barney does not ever do any work. (Standard)

or Barney never does any work. (Standard)

or Barney does no work. (Standard)

(adapted from Warriner 1982:236).

Some writers allow for the use of multiple negatives in certain situations. In Right, Wrong, and Risky: a Dictionary of Today's American English Usage, scholar Mark Davidson (2006:209) offers the acceptability of "emphatic double negatives...for dramatic effect," citing Rodney Dangerfield's famous, oft-repeated remark, "'I don't get no respect'."

As we have seen, multiple negation has a long and interesting history. In today's society, it is an acceptable feature in many languages, dialects, and social registers. Teachers of 'standard' English would do well to acquaint themselves with some of the historical and social background of this grammatical feature, including its connection to modern dialects which utilize multiple negatives, so that they may be better equipped to discuss the concept with their students. 


\section{CHAPTER V \\ THE MYSTERY OF AIN'T}

The previous chapter discussed the historical background of multiple negation; that is, the use of more than one negator to express a negative statement. This chapter carries on the theme of negation to focus on one particular example that has been the object of much criticism for more than 200 years. The word ain't has endured much name-calling, from being labeled a barbarism and a vulgarism, to the more recent moniker of substandard, or its euphemistic cousin, non-standard. It seems to be fairly common practice for some teachers in U. S. classrooms to reprimand students who use ain't, and to announce in no uncertain terms that "ain't is not a word!"

Unfortunately, despite the opinions of well-meaning teachers and others who tout this or similar lines of thinking, ain't is a word, and for several hundreds of years it has proven to be a quite useful word. Is it a "proper" word? Is it acceptable in formal written documents? These and similar questions have long been debated, and there is no easy answer. One thing seems certain, however. The fact that this word has been (and continues to be) at the heart of so much contention may indicate that words such as ain't play an important role in the development of our language. Individuals who insist that only persons of low education or socio-economic status say ain't would do well to take note of its longstanding popularity and to investigate the background of the word before attacking its many users. The purpose of this chapter is to take a look at the interesting 
history of this contraction, and to attempt to provide the reader with a fuller understanding of why ain't is worthy of some respect.

It was respected in the earliest days of its history, after all. Burridge (2004:102) notes that ain't has been part of the language, along with other contractions, such as can't, won't and don't, "since at least the seventeenth century." The OED online documents one of these early forms of ain't from Spightful Sister, by A. Bailey (1667:iii.i. 26): "Look you, Sir, I an't for complementical words; but here Stands the case."

Stevens (1954:196) posits that "[a] thorough investigation of the etymology of the contraction will undoubtedly reveal that historically it is no less reputable than any other verbal contraction.” Burridge (2004:102) supports this position by pointing out that during the seventeenth century (and probably the early eighteenth century), the use of ain't (spelled an't or $a^{\prime} n^{\prime} t$ ) was considered "perfectly respectable" and, in fact, the word was used by "even the most highly educated speakers" including Jonathan Swift, author of the commonly recognized novel Gulliver's Travels as well as many other writings, including political essays and poetry.

Stevens (1954:197) includes an example of Swift's use of ain't taken from a dictionary of slang edited by John S. Farmer in 1890: "from Swift's Journal to Stella, November 24, 1710, Letter ix: 'I ain't vexed at this puppy business of the bishops, although I was a little at first."”

Many other well-respected writers used ain't, according to O'Conner \& Kellerman (2010:48), who note that ain't "or variations of it can be found in the letters or diaries of Swift, Lamb, Byron, Tennyson, and Henry Adams... as well as characters of all 
classes in the novels of Fielding, Austen, Dickens, Thackeray, George Eliot, and Trollope."

O’Conner \& Kellerman (2010:49) also point out that "the early versions of 'ain't'" represented "a contraction of 'am not' and 'are not'." Whether this occurred as a result of natural changes within the language, or as someone's purposeful design, apparently it became rather handy to have one word that could be used instead of both amn't and aren't. This same word was later used to represent is not. Burridge (2004:103) imagines the sequence of changes as: “is not $\rightarrow$ isn't $\rightarrow$ int $\rightarrow$ ain't." O'Conner \& Kellerman (2010:49) estimate that "by the 1800s it was used for 'have not' and 'has not,' too, replacing an earlier contraction, 'ha'n't'." Evidence of this development can be seen in the fact that ain't can replace haven't in the perfect aspect, as in He ain't never been here.

But the question of the word's origin remains a mystery worthy of an episode on modern detective shows. How did ain't come about? And how did this word, which at one time was "routinely used by the upper classes as well as the lower, by the educated and otherwise, in the seventeenth, eighteenth, and nineteenth centuries" (48), become so poorly thought of by so many lexicographers and writers of usage manuals that it has often been labeled "a vulgarism" or "illiterate"? Many theories have been advanced in scholarly writings throughout the last hundred years or so. And, even though there is no "smoking gun," we find sufficient evidence to support the consideration of a number of possibilities.

In the case of using ain't in place of amn't, the literature seems to be pointing toward the possibility that ain't as an accepted contraction of am not may be, in part at 
least, attributable to a process of sound change called assimilation (Hudson 2000; McDavid 1941; Stevens 1954; Cheshire 1981). Barber, Beal \& Shaw (2009:42) define this "very common" process as "the changing of a sound under the influence of a neighbouring one," noting that "the word skant was once skamt, but the $/ \mathrm{m} /$ has been changed to $/ \mathrm{n} /$ under the influence of the following /t/," making the word easier to pronounce.

Is this what happened to amn't? Perhaps, but Hudson (2000:298) discounts the pronunciation “explanation" for two reasons: first, "because amn't is used in some dialects" and secondly, "because the normal reaction to a pronunciation problem is to fix the pronunciation not to eliminate the word."

However, Stevens (1954:199) apparently believes the assimilation theory is worth consideration. He offers an explanation given by Professor Anders Orbeck, of Michigan State College:

am not might have been syncopated into the form amn't. Assimilation to an n't followed; then the simplification of the long consonant might have been accompanied by a lengthening of the vowel to Early Modern [æ:], from which the present diphthong would develop.

Stevens (1954:199) also cites linguist Otto Jespersen (1928: 430), who proposes another possible source: "Are not became arnt, which may well have lost its [r] early and, with compensatory lengthening, yielded [a:nt]. From this form, ain't could have developed quite regularly."

McDavid (1941:57-58) argues for the consideration of "a common origin" of the constructions ain't I and aren't I. McDavid's discussion compares dialectal developments 
in the pronunciation of I ain't and I aren't. He points out that within the Central-Western American dialect, "[r] was retained in the combination [arC]" (in which [a] represents the sound of the $a$ in father and [C] represents "any stop, spirant, affricate, or cluster"); however, in other dialects, namely, "the British Received Standard, the dialect of Eastern New England, and most of the Southern American dialects" the "[r] in such a combination became actualized only as a shwa-glide [a $\square \mathrm{C}]$ or as length [a:C]."

McDavid describes how additional dialectal developments led to the lowering or raising (and diphthongization) of vowels, resulting in pronunciations such as ['aj 'ejnt] and ['aj 'ant]. The latter form "had no established orthographic representation"; therefore, "the spelling characterizing the three forms ['wi 'ant, 'juw 'ant, 'ðej 'ant], was adopted" resulting in the form I aren't. This form was used by the dialect group with the highest level of "social prestige" and therefore "their forms became the norm for social elegance" (59).

McDavid reports the possibility that ['aj 'ejnt] "lost favor because of the spread of the socially privileged form ['aj 'ant]." Eventually, however, the status of this privileged form and the form ['aj 'arnt] also lessened, "probably due to the influence of a pseudological attitude, which objected on orthographical premises to a form I aren't as the negative of I am" (59).

But I aren't is not the only construction that seems a bit disconnected from its non-contracted form. Stevens (1954:198) discusses the origin of the contraction won't in offering an additional theory for a dialectal origin of ain't:

The contraction won't, for example, is the product of an alternate present indicative form, wol, in the East Midland dialect, which both Gower and 
Chaucer use frequently. Won't could not have had its origin in the North, where the present indicative was invariably wil or wel. Quite the same type of dialectal origin may exist for the word ain't, which might be derived from the shortened Northern English verb ha combined with the negative not.

This theory is supported by E. Payson Willard (1936:2, cited in Stevens 1954:200), who argues for a dialectal derivation of ain't from the verb have instead of am:

'(1) It is used in all three persons and is not confined to the first person singular. (2) As an auxiliary it has the meaning of have much more than that of be. (3) Short forms of have can be found in the older English and in dialect English (e.g., han in Chaucer and $h a^{\prime}$ in Burns). (4) It is sometimes aspirated. (5) $\mathrm{Ha}$ had the long-a sound in the word Halfpenny (which is pronounced by Englishmen as if the first syllable were hay); hence the ha of have may have been given this sound also'.

One feature of ain't that should give pause to those who commonly attack users of the word is the unusual aspect pointed out by Cheshire (1981:366), who says that the use of "one form" (ain't) for two verbs (have and be) "is the result of a diachronic coincidence." And this may be the source of much of the angst about ain't. The evidence seems to indicate that attitudes toward ain't started changing (for the worse) when people started using the word not just in place of amn't and aren't, but also as a substitute for isn't, haven't, and hasn't (Burridge 2004; O'Conner \& Kellerman 2010). 
While it may be true that ain't derived from have, a few scholars over the years seem to perceive these representations as even more vulgar than the derivations from $b e$. Merriam Webster's Dictionary of English Usage (1989) offers the following quote from a graduation speech given in 1846 to an all-girl high school, in which "a man named Peabody...advises great care and discretion in the employment of the negative contractions, working his way through can't, don't, haven't, isn't, hasn't, didn't, couldn't, wouldn't and shouldn't..." He ended this long list with the worst offender of all: 'Won't for will not, and ain't for is not or are not are absolutely vulgar; and ain't for has not or have not, is utterly intolerable' (Brice-Heath 1980:61).

This "all-purpose" word may have become too popular for its own good. Pyles (1964:206) notes that the many predecessors and variants of ain't were likely in use long before they appeared in written form, since "contractions are in their very nature colloquial and thus would have been considered unsuitable for writing, as most people still consider them." However, despite this fact, many educated (and respected) writers, such as William Congreve (1695), Sir John VanBrugh (1696), and Jonathan Swift (1710) frequently employed forms of ain't as a contraction for am not, are not, and is not. Here are a few examples:

'MISS PRUE. You need not sit so near one, if you have any thing to say, I can hear you farther off, I an't deaf-William Congreve, Love for Love, 1695'.

'LORD FOPPINGTON. ...these shoes a'n't ugly, but they don't fit meSir John Vanbrugh, The Relapse [, 1696]'. 'an't you an impudent slut,' [and] 
'Presto is plaguy silly, tonight, an't he?'-Jonathan Swift, in his Journal to Stella, 1710 (The Merriam-Webster Dictionary of English Usage 1989:60).

Even the contraction han't appeared in late seventeen-century writing. Take, for example, this line from Act V, Scene IV, of The Country Wife, by William Wycherley (1675): “Gentlemen and ladies, han't you all heard the late sad report of poor Mr. Horner?" (Web). Of course, many other contractions appear in this play, such as shan't, 'tis, sha't (meaning 'shall not'), I'll, let's, d'ye, on't, an't (meaning 'and it'), and more.

The fact that contractions (including forms of ain't) were included in prose and dramatic writing indicates the acceptability of such forms during that era. Haugland (1995:179) notes that "[t]he appearance of a variety of contracted forms in the grammars and spelling books" of the early eighteenth century "is an indication that these forms were not considered entirely colloquial, epistolary or poetic, but were being established as legitimate variants even in scholarly prose." During the mid-eighteenth century, however, language "authorities" began to attack some of these abbreviated forms.

Sairio (2010:94) points out that this "growing acceptance of contractions took a turn when Swift and Addison, who were bothered by the inelegant consonant clusters brought by deletion, attacked contractions in the 1710 and 1711 issues of the Tatler and the Spectator.” In section 135 of The Spectator, Addison (1711) writes that English "[abounds] in Monosyllables" but "where the Words are not Monosyllables, we often make them so, as much as lies in our Power, by our Rapidity of Pronounciation [sic]..." (1711, Morley 1891). Addison attacks the "closing in one Syllable" of words such as "drown'd, walk'd, arriv'd for drowned, walked, arrived" as having "very much 
disfigured the Tongue, and turned a tenth part of our smoothest Words into so many Clusters of Consonants." Addison also mentions the fact that "on other Occasions we have drawn two Words into one, which has likewise very much untuned our Language, and clogged it with Consonants, as mayn't, can't, shd'n't, wo'n't, and the like, for may not, can not, shall not, will not, \&c.” (1711, Morley 1891).

Jonathan Swift's (1710) letter in issue 230 of The Tatler expresses his concerns about some of the common errors that seem to appear frequently in the "polite Way of Writing." He exposes some of the evidence of "the continual Corruption of our English Tongue" which, in his opinion, is the result of the "two [e]vils, Ignorance, and want of Taste." Some of the chief offenders echo Addison's criticisms in The Spectator regarding monosyllables. He specifically mentions the following contractions, which appeared in a letter that he reported having received "some Time ago": 'cou'dn't;' 'ha'n't;' 'don't;' 'can't;' 'do't;' 'shan't'. (1710, Web).

His objections involve several key areas. First, he seems certain that the manner of writing may not be understandable by future generations. Next, he points out "the Abbreviations and elisions, by which Consonants of most obdurate Sound are joined together, without one softening Vowel to intervene..." serves "only to make one Syllable of two, directly contrary to the Example of the Greeks and Romans" (1710, Web). By mentioning the Greeks and Romans, he seems to be holding up the Classical languages as an example of "pure languages" that should be emulated, not turned away from.

Swift continues his attack on these "refinements" as being "of the Gothick Strain, and [having] a natural Tendency towards relapsing into Barbarity, which delights in Monosyllables, and uniting of mute Consonants; as it is observable in all the Northern 
Languages" (1710, Web). The American Heritage Guide to Contemporary Usage and Style (2005:21) states that "[a]in't and some of these other contractions came under criticism in the 1700 s for being inelegant and low-class, even though they had actually been used by upper-class speakers," among them Swift himself.

And it seems that things have not changed much since the early eighteenth century, at least where ain't is concerned. Upper-class speakers and highly educated individuals may still incorporate words like ain't into their speech, especially in informal situations. Also, as Greenbaum (1996:131) points out, “American politicians may use ain't in public speeches to convey a folksy tone."

Over the years, the popularity of ain't has continued to rise, if we may take its frequent appearance in society as evidence. The word "has made its way into a host of catchphrases and songs: 'ain't it grand to be blooming well dead?; 'ain’t love grand?'; 'there ain’t no such animal'; 'ain't that something?'; 'it ain't necessarily so; 'if it ain't broke don't fix it'; 'Is you or is you ain't my baby?'” (Fowler \& Burchfield 1996:38).

In literature, the word ain't "is an undisputed element in Cockney speech" (Fowler \& Burchfield 1996:37), a dialect which Matthews (1937:325) says emerged at the end of the [eighteenth] century and was taken over by Dickens and his contemporaries [and] was in the main the survival of seventeenth-century pronunciations which had been abandoned in Standard English because of the eighteenth-century movement towards a regular speech.

In addition, the use of ain't is often noted as a feature of some nonstandard English dialects (Greenbaum 1996), including Appalachian English (Luhman 1990) and 
African American English, also known as Black Vernacular English (Walker 2005:2) in the U.S. In these dialects, ain't typically replaces negative forms of be or have, but Walker notes that in African American English (AAE) ain't also "alternate[d] with did (and more infrequently) $d o$, a pattern not found in other varieties of English."

As we have seen, the word ain't has played a very active role in the English language over the past several centuries. It is interesting that the existing literature on ain't seems to have one thing in common: none of it provides a definitive answer on the origin of this word. Scholars may offer opposing or complementary theories, but for various reasons the origin of ain't remains elusive. Many opportunities exist for further research. What we do know and humbly recognize, however, is that the word ain't has a long and mysterious past. And despite the fact that ain't has been, well, blackballed from "acceptable" and "proper" usage, most of us employ this word from time to time. As O'Conner \& Kellerman (2010:48) point out, "The much-maligned contraction is the poster child for poor English and has been for generations, never mind that millions use it and everyone else knows what it means." And whether it derives from be, have, or from some other source, or is the result of assimilation due to our language's striving for efficiency or ease of pronunciation, ain't is definitely a word. 


\section{CHAPTER VI}

\section{THE $A K S$ ATTITUDE}

What thoughts pop into your head when you hear axe, and the speaker is not referring to an implement used to chop down a tree? Do the hairs on the back of your neck stand on end? Do your eyebrows rise up, even slightly? If you know what I am talking about, and you understand the shift in attitude that results in a bodily reaction such as those mentioned, then the message of this chapter is for you.

I must admit that from time to time I have experienced these reactions myself, but instead of lashing out at the speaker, a strong curiosity about the usage has spurred me on to study the history of this word. As I have researched the etymology and the sociological background of ask, my "teacher-self" has been encouraged to be somewhat more tolerant of variations such as this. But it is not easy to erase the memories that negative attitudes can create.

And somehow this particular usage above many others can incite even the most genteel teacher of the King's English (or “the Queen's English" if you prefer) to riot. I have observed meek, mild colleagues in a high school English department rant and rave at a student whose offense was merely that of transposing two sounds in a three-letter word. Not a pretty sight.

The indignation that surfaces in teachers and non-teachers alike at the sound of this "mispronunciation" is very common. Why do so many people get upset at hearing 
$a k s$ for $a s k$ ? Is it because they expect the letters to be sounded out in the order in which they appear? Have our ears grown so accustomed to hearing the "correct" pronunciation that the other grates on our nerves? Or does the "incorrect" version bring some "baggage" with it? Machan (2009:40) suggests that "[a] process like metathesis...becomes stigmatized as external corruption rather than internal change only when speakers, for whatever non-linguistic reasons, assign negative value to these linguistic phenomena..."

Perhaps aks has been stigmatized because it is a feature of a dialect often referred to as "Black English" or "African American Vernacular English" (AAVE), and therefore, many speakers of English believe that it does not belong in the preferred version of English, the so-called Proper English.

Lippi-Green (2007:179) comments that “[p]ejorative attitudes toward AAVE by non-blacks are easy enough to document..." and in fact, aks "is characterized as the most horrendous of errors" by non-AAVE speakers. Lippi-Green adds that "[o]ne of the most salient points of phonological variation which is strongly stigmatized from outside the black community might be called the great ask-aks controversy."

This usage may be controversial because it has been included by many scholars and language authorities under the "Black English" umbrella. But how did aks become associated with the AAVE dialect? McClendon (2004:17) reports that scholars have traced axe for ask as part of a pidgin used by slaves brought to America from various countries and regions. He proposes that "during slavery, many words were changed in spelling and in pronunciation. With Africans unaware of these alterations, language changes among us didn't always follow." 
Eventually the usage was labeled as "slang," "unconventional," or "nonstandard." The Concise New Partridge Dictionary of Slang and Unconventional English (Partridge, E.; Dalzell, T., \& Victor, T. 2008:7) defines the variant aks as "A familiar mispronunciation, especially in black and youth usage, UK." The American Heritage Guide to Contemporary Usage and Style (2005:41) comments that the pronunciation of ask as aks, which is "sometimes spelled ax or aks, is often identified as a feature of African American English." And while aks and ast (another variant pronunciation) are both considered "...nonstandard...they occur fairly frequently, especially in the southern or central sections of the United States.” But apparently the authorities are not entirely in consensus about assigning aks to the list of patterns of usage recognized as Black English. The guide goes on to say:

While it is true that the form is frequent in the speech of African Americans, it is also heard in the speech of white Americans as well, especially in the South and middle sections of the country. It was once common among New Englanders, but has largely died out there as a local feature (41).

Lippi-Green (2007:179) adds that while it is commonly believed that "the aks variant [is] an innovation of the AAVE community" this usage is actually much more widespread, being "found in Appalachian speech, in some urban dialects in the New York metropolitan area, and outside the US in some regional varieties of British English.” O'Conner (2010:52) concurs, recognizing that this “AX pronunciation isn't limited to African Americans," and admitting that she "heard it when [she] was growing up in Iowa, from whites as well as blacks.” 
So, if the variant pronunciation is not simply a feature of a particular dialect, then how do we explain the sound of these letters switching places? Is there a logical, rational explanation for it? Or are the individuals who frequent this pronunciation simply ignorant of their error? The following discussion will attempt a historical explanation of the usage, and perhaps urge the reader to a less extreme reaction when the letters of this word (or of other words) are seemingly reversed in the future.

As we have seen, the pronunciation aks is most often labeled a dialectal feature of AAVE; however, the history of the English language provides a much older and varied record for the Modern English ask. In the Oxford English Dictionary (OED) (Oxford University Press 2013) we find that ask developed from two very old forms: áscian and ácsian. It remains unclear which form appeared in the language first, although ácsian was apparently more frequent.

The Merriam-Webster Dictionary of English Usage (1989:633) claims that the $s k$ order was the earlier form, deduced "by comparison with cognate forms in other languages.” However, Curzan \& Adams (2012:3) report that “...ask can be traced back to the Old English verb ācsian, the form used throughout England through the eighth century." Fromkin, Rodman \& Hyams (2007:281) state that "in Old English the verb was aksian, with the /k/ preceding the /s/." Denham \& Lobeck (2009:117) maintain that the "two forms...coexisted" in Old English.

Both forms are attested as early as 885 in the OED (Oxford University Press 2013), appearing in Ælfred's translation of Boethius' Consolation of Philosophy: "Pæt is pæt ic pé ær ymb acsade..Đisse spræce ðe ðu me æfter ascast" and “Se ðe ymb pæt ascian wile" (xxxix. §4; emphasis mine). (The OED notes several additional forms from 
the ninth century through the end of the OE period: áhsi-, áxi, áhxi-, áhxsi-, áxsi-an, gan, -gean, and æcsian.)

Whichever form appeared first, scholars agree that a process of sound change called metathesis was instrumental in the reversing of the sounds made by the $s c$ / $c s$ cluster. According to Fowler \& Burchfield (2000:492), metathesis is "the transposition of sounds or letters in a word," such as the pronunciation of ask as aks (axe). Another usage guide (Merriam Webster 1989:633) depicts metathesis as "the process whereby a sound hops out of its proper place, so to speak, and pops up elsewhere in the word, or switches places with another sound in the word."

But this is not something that language experts just noticed in the last century. In fact, if we look at some everyday words we can see the evidence of metathesis all around us. Consider the Old English words brid and thrid. Would you recognize these words as bird and third? Lerer (2007:66-67, 273) tags several Modern English words, such as bird, ask, through, and bright, as examples of "...metathesis explaining a permanent, historical change in pronunciation."

But, as Lerer (2007:273) points out, "[t]he reversing of two sounds in a sequence" is sometimes simply "a case of mispronunciation" as in irrevelant for irrelevant, or nukeler for nuclear, and many more. David Crystal (1980:225) offers a broader definition of metathesis than simply a switching or reversal of two sounds or letters in a word, but further as “... an alteration in the SEQUENCE OF ELEMENTS in a SENTENCE-usually of sounds, but sometimes of SYLLABLES, WORDS, or other UNITS." Crystal classifies some metatheses as "PERFORMANCE ERRORS," and includes the pronunciation aks for ask under 
the sub-category of "TONGUE SLIPS" (225). Is it possible that the OE metathesis of ask was originally a slip of the tongue?

It should be noted that during the OE period two different sounds were possible for the sc combination. Pyles (1964:38-39) explains:

In early Old English times sc symbolized [sk], but during the course of the Old English period the graphic sequence continued to indicate the later development of [sk] into the sound symbolized from Middle English times to the present by $s h$. The $s h$ was an innovation of Anglo-Norman scribes (OE sceal-ME and ModE shall), who earlier had used s, ss, and sch for the same purpose. The digraph $s c$ thus occurs after the Old English period only in borrowed words."

According to Baker (2012:15-16):

“sc is usually pronounced [ $\square]$, like Modern English sh: scip 'ship', æsc 'ash (wood)', $w \square$ scan 'wish'. But within a word, if $s c$ occurs before a back vowel $(a, o, u)$, or if it occurs after a back vowel at the end of a word, it is pronounced [sk]: ascian 'ask'..., tūsc 'tusk'. When $s c$ was pronounced [sk] it sometimes underwent metathesis (the sounds got reversed to [ks]) and was written $x$ : axian for ascian, tux for tusc. Sometimes $s c$ is pronounced [ $\square$ ] in one form of a word and [sk] or [ks] in another: fisc 'fish', fiscas/fixas 'fishes'.

Wright \& Wright (1914:156) note that "Medial sc often underwent metathesis to cs (written x), especially in late WS., as axe, ashes, āxian, to ask, fixas, fishes, waxan, to wash, beside asce, āscian (OHG. èiskon), fiscas, wascan." 
Apparently, though, the axe variants were more popular than the asc-forms during the OE period, as evidenced by their significantly higher ratio of use (266 to 5) in Old English texts such as Beowulf and others listed in the Dictionary of Old English Web Corpus (Slade 2009). In the Oxford English Dictionary (Oxford University Press 2013) we note several variants attested prior to 1100, such as: ahsige, ahsian, ahxiað, acsiað, ahxiað, axsodon, ahsude [n], axian, and axigean (c1000); and acsode (a1038). The next century brought two new forms, eskien and esca (1175), and the $13^{\text {th }}$ century introduced asskenn and acseð (1200), as well as aske (1220), easkeð (1230), axinde and axestu (1250), followed by axien and axi (1275), and aschede, asche, and essep 1297). The first half of the $14^{\text {th }}$ century introduced forms such as: eschte, oxist, axed, oxy, oxed, acsy, axen, askis, oxi, oxsep, acsy, and oksep. From the last half of the 14th until almost the end of the $16^{\text {th }}$ century, the ax forms seemed to gain momentum; however, the ask forms were still in use, as can be seen in the following table: 
Table 1: Forms of Ask, 1366-1697

\begin{tabular}{|c|c|c|c|}
\hline Year composed: & Form: & Year composed: & Form: \\
\hline 1366 & asked & 1544 & axe \\
\hline 1370 & asch & 1549 & asketh, axed \\
\hline 1374 & $\begin{array}{l}\text { naxe (negative } \\
\text { form), axe }\end{array}$ & 1559 & axe \\
\hline 1377 & axen, axed & 1562 & axed \\
\hline 1380 & axeth, ax & 1564 & axeth \\
\hline 1382 & $\begin{array}{l}\text { askist, aske, } \\
\text { asken, asketh }\end{array}$ & 1570 & axe \\
\hline 1386 & axe & 1580 & aske \\
\hline 1387 & i-axed, axeth & 1583 & asketh \\
\hline 1393 & axed, axen & 1584 & axes \\
\hline 1395 & axide, axen & 1595 & aske \\
\hline 1400 & $\begin{array}{l}\text { hask, aske, asked, } \\
\text { askid, to axen }\end{array}$ & 1597 & aske \\
\hline 1405 & axe & 1598 & aske \\
\hline 1410 & en & 1600 & aske, asking, askt \\
\hline 1420 & $\begin{array}{l}\text { asshes, asshe, } \\
\text { asshet }\end{array}$ & 1606 & askt \\
\hline 1430 & ashed, axip & 1608 & aske \\
\hline 1440 & asckid, axit & 1611 & aske, asketh \\
\hline 1450 & axe, axse, aske & 1612 & asking \\
\hline 1455 & askid & 1614 & asketh \\
\hline 1460 & axen, asse & 1615 & aske \\
\hline 1477 & axid, axed & 1616 & aske, asketh \\
\hline 1483 & axe & 1623 & ask \\
\hline 1484 & asking & 1644 & asking \\
\hline 1485 & aske & 1647 & aske \\
\hline 1500 & ast & 1649 & ask \\
\hline 1503 & axith & 1661 & ask'd \\
\hline 1509 & asshe & 1663 & asking \\
\hline 1523 & aske & 1667 & to ask \\
\hline 1535 & axe, ask & 1671 & ask \\
\hline 1538 & axe & 1697 & ask \\
\hline 1540 & askes & & \\
\hline
\end{tabular}

(Note: Information taken from the entry "ask," Oxford English Dictionary online. Oxford University Press 2013).

The variety of forms attested between 1000 and 1350 can be explained by Fisher (1992:11), who notes that "English writing from 1066 to Henry V was all in local 
dialects... [which] were not uniform in pronunciation, spelling, grammar, or vocabulary." Even within an author's writing, variation can be observed. A search of the Corpus of Middle English Prose and Verse indicates that Geoffrey Chaucer used forms of both ask and axe in The Canterbury Tales. For example, in The Miller's Tale (Lines 87 - 89), reportedly written between 1380 and 1390, we find axed: "If that men axed him in certain houres / Whan that men sholde have droughte or elles showres, / Or if men axed him what shal bifalle..." (Chaucer, Greenblatt \& Abrams 2006:193). Then, in The Prologue of the Man of Law's Tale, we find asken and aske: (Lines 101 - 102) "To asken help thee shameth in thin herte; / If thou noon aske, so soore artow ywoundid /" (Chaucer \& Mann 2005:167).

Chaucer, whom some call "the father of Modern English," wrote "in the dialect of upper-class London... which would, in the next generation, after Henry V, become the prestigious form of English for government and business" (Fisher 1992:11). But the variants that existed in writings such as The Canterbury Tales had to be managed. As Lynch (2009:169) points out, to find ask in one line and axe in another (just for one example) must have been confusing to the reader. In Chaucer's day, however, there was apparently tolerance for some flexibility. After all, it would have been impossible to maintain a standard spelling for words when so many different scribes were copying manuscripts. This lack of uniformity may have opened the door for the gradual emergence of "standard" English. At the very least it probably contributed to the atmosphere of the period, in which such variety had become commonplace.

The introduction of the printing press into England in 1476, however, less than a century after the death of Chaucer (1400), would prove to be a pivotal event in the history 
of the English language. Finally, the means was available to reproduce important documents and literature legibly and relatively quickly. Not only that, but also the ability to maintain consistent spellings had become a possibility. Perhaps aks was one of the many "casualties" in the journey toward standardization of spelling and usage influenced by the printing press. According to the OED, by 1570 the $s k$ versions of the word had emerged as the preferred spelling in published writings.

After having enjoyed what seems rather equal status with aks for a millennium or longer, how did axe acquire its current stigma as a nonstandard usage? First, the $s k$ forms had taken over as the literary "standard" since the late $16^{\text {th }}$ century, about 100 years after William Caxton set up his printing shop near the Royal Court in Westminster. During this era, the orthography of the printed word most often reflected the pronunciation of the most prominent members of society (subject to the whims or restraints of the typesetters). We may assume that as the $a x$ forms became less often used by persons of high standing (scholars, writers, lawyers, government officials), this practice was gradually picked up by their assistants, secretaries, clerks, and maybe some of the household help, and so on down the social ladder, until persons who said $a x$ were looked upon as uneducated and uninformed.

Since the court was based in Westminster, and London was the center of commerce, it was natural that Caxton chose the London dialect as the model for printed materials. But at that time, according to Crystal (2003:54-55), London was "a dialectal hybrid (with the City influenced by the Essex dialect, and Westminster, some distance further west, showing the influence of Middlesex)." This mixture of dialects is undoubtedly responsible for some of the variation noted in printed materials. Some of the 
variation, however, was due to the native tongues and backgrounds of the typesetters. Crystal (2003:66) explains that

Many of them were foreigners, who introduced their native conventions at will, and who were uncertain of orthographic traditions in English. Proofreading was not always carried out by educated people, so that errors were promulgated. Because there was only a limited amount of type, arbitrary spellings were often introduced.

To be fair, using a printing press was quite different from using quills and inkwells. Lynch (2009:170) describes how individual "lead slugs" had to be placed "in a metal rack," and sometimes there was not enough space for all of the letters. Sometimes there was too much space. Crystal (2003:66) notes that typesetters would often add or omit letters, such as "a final $e$ " to even out the end of a line of type. This sort of "justification" is done nowadays by publishing house computers, which offer programmable spacing and do not require manual adjustments. Obviously, the innovation of printing was like many of the technological advances of the last couple of decades. There are always "bugs" that have to be worked out.

As printing technology improved and typesetters became more skilled, the spelling of printed words gradually became more consistent, despite changes in pronunciation due to the Great Vowel Shift, among other influences. However, there was still so much dissension regarding the language that respected scholars and writers pushed for the establishment of an academy (such as the French, Spanish, and Italian language academies) to resolve the issues once and for all. When those efforts failed, some of those same individuals advocated for a reference book, such as a grammar or 
dictionary that could function as the authority regarding language usage and grammar. (Rather, the author of such a publication could act in that capacity.) Lynch (2009:73) points out that although many dictionaries had been published during the $16^{\text {th }}$ and $17^{\text {th }}$ centuries, none of them was considered "authoritative" enough to "settle disputes" and "arrest linguistic decay."

Lynch (2009:74) describes how a group of printers banding together decided on Samuel Johnson as the man to produce the ultimate dictionary that could fix the problems with the language and establish once and for all how words should be pronounced and spelled. And, after nine years of painstaking work, Samuel Johnson and his six assistants put forth an English dictionary that turned out to be quite different from all the previous English dictionaries (and probably rather different from what the cohort of printers had expected). This was not simply a dictionary of "hard words," such as the dictionaries produced by Robert Cawdrey in 1604 and Henry Cockeram in 1623 (72-73), nor was it an "etymological" dictionary concerned chiefly with "comprehending the derivations of the generality of words in the English tongue," such as the publication by Nathan Bailey in 1721 (239).

Instead, as Lynch (2009:78-79) notes, Johnson focused his search on "important" and "interesting words" that could be found in English literature and other writings. He purposely omitted "slang and nonstandard English," as well as "very old and very new words" and words that represented "technical terms and specialized jargon." Further, Lynch describes Johnson's Dictionary as “one of the largest anthologies of English literature ever published, and one of the largest dictionaries of quotations" (92). By 
admitting ask as an entry in his dictionary, Samuel Johnson had sealed the fate of the variant $a x$.

Despite the many changes in the language brought about by the innovation of printing, people continued to speak in regional dialects. And, as groups began to colonize the New World, these dialects went with them to America. In his Dissertations on the English Language, Noah Webster (1967 [1789]:386) noted that "the word ax for ask was used in England, and even in the royal assent to acts of parliament, down to the reign of Henry VI..." and the verb "to $a x$ is still frequent in New England." How interesting that even though $a x$ had taken a back seat to ask, it had not disappeared, and it was apparently still commonly used (at least in speech) by the earliest American settlers.

Even though ask had become, in effect, the "standard" English verb form, there was no way to enforce this in speech. Therefore, people would continue to use ax until something inspired an alteration in their speech habits. Did education play a role in advancing the use of ask? Most likely. It is understandable, then, that some members of society would retain the older pronunciation. Those individuals who were not privileged to attend school or to receive more than a basic education might be less likely to acquire this new habit.

Education may have played a role, but other factors were undoubtedly involved. Rickford \& Rickford (2000:102) attribute most differences in the speech patterns and sounds of black and white speakers to "cultural and sociological factors." Wilde (1997:52-53) comments that just as with individuals whose native language is other than English, "[t]he pronunciation of a child when she is reading in English and her spelling when she writes in English will of course be inclined to reflect the phonology of her first 
language" and in many cases of individuals who habitually employ the aks pronunciation, the first language is the AAVE dialect.

In other cases, however, the "first language" might be the dialect known as SAE, or Southern American English. Bailey \& Thomas (1998:87-88) include "metathesis of final /s/+stop" such as pronouncing ask as ax or grasp as *graps as one of several "oldfashioned features of Southern phonology that are rapidly disappearing in white speech" but that continue to be identified as features of AAVE. It seems curious that this feature has decreased so dramatically in white speech but persists in the vernaculars of many African American speakers.

As we have seen, then, the current pronunciation aks for ask is not necessarily simply one of the many features of a dialect known as AAVE, Black English, or even Southern American English, but instead it reflects a long and interesting history. The fact that the etymology of ask includes many different spellings (and therefore, many different pronunciations) reminds us that people from all over England had developed unique dialect features over hundreds of years, and although they were all speaking or writing "English," they often did not completely understand their neighbors to the north or the south. In a similar way, we in the $21^{\text {st }}$ century may not always understand the speech of every person we meet, or understand why their pronunciation differs from ours. By exploring the history of a usage such as aks and discovering the ways our language has changed and developed over the centuries, we may learn to appreciate more deeply the cultural and linguistic backgrounds of those around us. 


\section{CHAPTER VII}

\section{NEVER END A SENTENCE WITH A PREPOSITION?}

The preceding two chapters have addressed particular words and phrases that had once been considered acceptable English usage, but at some point in their history had transitioned into a lesser status. Eventually these usages became stigmatized and were labeled barbarisms, vulgarisms, illogical, improper, incorrect, or inelegant. The current chapter carries on the theme of acceptability with an examination of a particular problem of usage which was criticized by grammarians and scholars in the eighteenth century (and likely even earlier), and which continues to plague teachers (especially teachers of English) and their students in classrooms today. This discussion explores the origins of the proscription regarding the placement of a preposition at the end of a sentence. By uncovering and understanding the legacy of this "rule," we teachers may be better prepared to guide students toward using or avoiding this feature of English.

Scholars have posed several possibilities as the basis for the 'rule' about using a preposition at the end of a sentence. One popular assumption is that the proscription came about due to the fact that the word order of Latin sentences does not permit this option (Milroy, L. 1998). The influence of Latin grammar on the grammar of English has been clearly shown by numerous scholars, including: Bauer \& Trudgill (1998); Bex \& Watts, (1999); Crystal (2003); Klammer, Schulz \& Della Volpe (2010); Leonard (1962); Lynch (2009); Partridge (1973); and Tieken-Boon Van Ostade (2008b). 
In fact, Watts (1999:47), who studied the "discourse practices" of some of the "grammar writers" of the eighteenth century, namely Greenwood (1711), Jones (1724), Duncan (1731), Saxon (1737), and Lowth (1762), noticed that the grammarians he examined share a common feature: they all structured their grammars around "eight parts of speech" which "correspond exactly with those proposed for the grammar of Latin, and they are simply taken over and applied to English." However, the grammarians whose work Watts examined may have differed in the 'word classes' they included (there was apparently some variation and experimentation regarding which 'parts of speech' were really 'word classes' and which may have been considered sub-classes by some grammar-writers during the eighteenth century).

For example, while Greenwood (47) lists 'Noun, Pronoun, Verb, Participle, Adverb, Conjunction, Interjection, Preposition', Jones (48) divides them into three basic groups: '1. Nouns; 2. Verbs, [and] 3. Particles'. Jones places the remaining 'parts' within these three groups: adjectives and participles are located within the noun category (as 'Nouns Epithets'); and adverbs, prepositions, conjunctions, and interjections fall under the particle category. Saxon (49) names the same three groups as Jones, adding a fourth called the 'adnoun,' a category that includes pronouns and participles. Within the noun category he includes adjectives, and under the particle designation are 'adverbs, conjunctions, prepositions, and interjections'. Duncan (49) uses the same word classes as Greenwood, but Lowth (50) makes two slight alterations, resulting in nine actual 'parts of speech'. He lists adjective as "a word class in its own right... partially subsum[ing] the former word class 'particle'." Finally, he creates a separate word class for 'article', reflecting a feature of English that Latin does not possess. 
Watts (1999:54-55) summarizes his study as follows: “...both the insistence on referring to Latin and also the definition of grammar and of the parts of speech show a relatively high level of consistency in the discourse practices of grammar writers throughout the period from 1711 to $1762 . "$

It should come as no surprise then, that the grammar of Latin has been named as the source of several other dictates of English grammar, as well. For example, according to Hitchings (2011:11-12), the "prohibition" against splitting an infinitive "originates in a regard for Latin" and is "one of the most enduringly contentious subjects in English grammar." One of the 'language myths' discussed by Bauer (1998:137) that has become a convention of written English is "the use of the nominative as the case of the subject complement... and this involves saying It is I rather than the usual modern English pattern... of It is me." “The objection to It is me,” says Bauer (1998:132) “is based on Latin grammar."

Another point in the discussion of the origin of the proscription against endsentence prepositions is the meaning and the history of the word itself. As defined by Morwood (2000:xiv), a preposition is "a word that stands in front of a noun or pronoun to produce an adverbial phrase. In Latin it will be followed by the accusative or ablative: ante merīdiem = before midday." And of course, the word's prefix tells us that a preposition should precede its object. A search for "preposition" in an online etymology dictionary provides these details: the word preposition comes from a "late $14^{\text {th }}$ century...Latin" word "praepositionem," which came from two smaller words: "prae" 'before' + "ponere” 'put, set, place' (Web). 
But the meaning of the word and the fact that English grammar was heavily influenced by the grammar of Latin are simply two pieces of the puzzle of how this "rule" came into existence. To get to the heart of this mystery, we have to start naming names. Tieken-Boon Van Ostade (2011:3) notes that the eighteenth-century grammarian "generally blamed for having first formulated the rule against preposition stranding," among other rules, is Robert Lowth (1967 [1762]:127-128), whose A Short Introduction to English Grammar provides the following observation:

The Preposition is often separated from the Relative which it governs, and joined to the verb at the end of the Sentence ... as, 'Horace is an author, whom I am much delighted with.' ... This is an Idiom which our language is strongly inclined to; it prevails in common conversation, and suits very well with the familiar style in writing; but the placing of the Preposition before the Relative is more graceful, as well as more perspicuous; and agrees much better with the solemn and elevated style (emphasis mine).

Despite the frequent association of Lowth with the proscription about ending sentences with prepositions, Leonard (1962:98) notes that "nobody in the eighteenth century appears to have tried hardening this sentence-order into a rule." Garner (2000:268) concurs with Leonard, saying that "Lowth's statement about prepositions was hardly intended as a "rule." Tieken-Boon Van Ostade (2011:7) is concerned that "[t]he widespread lack of scholarly interest in Lowth's grammar has led to much prejudice and misunderstanding about his motivations for undertaking to write the grammar," as well as "the reasons for his approach to grammar, and even about the approach itself." She notes that "Lowth wrote his grammar for his eldest son, Thomas Henry, as a means of 
facilitating his learning of Latin by the time he would be old enough to enter grammar school" (9), and therefore “...was surprised by the popularity of his grammar, which he originally appears to have treated as a mere incidental publication, a small book that was not to be taken too seriously" (20). Lowth certainly did not imagine that his 'incidental publication' would eventually lead to his becoming one of the best-known grammarians of the eighteenth century.

However, Chapman (2008:36) has noted that "[i]f we need an eighteenth-century icon for prescriptivism, a better choice than Lowth would be [Lindley] Murray, who stands more clearly at the head of the pedagogical and prescriptivist tradition." TiekenBoon Van Ostade (2011:8) adds that because Murray (1795) had "derived" much of his grammar "from Lowth...it is only through Murray that Lowth's influence in shaping the rules of Standard English much as we know it today came about."

The stricture about preposition stranding is just one of many proscriptions that have been attributed to Lowth. But he was not the first (or the only) grammar-writer to include his thoughts on this topic, which at least indicates that such a "rule" existed in the general discourse about grammar. Published about one month before Lowth's A Short Introduction, a grammar written by Joseph Priestley (1969 [1761]:50-51) cautioned against being overly concerned about the preposition-at-the-end of a sentence usage, as long as the sentence remained pleasing to the ear and harmonious with the rest of the writing:

With respect to real harmony, it is absolutely indifferent whether a period close with a monosyllable, or otherwise, provided the monosyllable, considered as connected with the words adjacent, have no disagreeable 
cadence; for it is not the ear, but the understanding, that perceives the distinction and interval between words in the same clause of a sentence, when they are regularly pronounced. It is often really diverting to see with what extreme caution words of such frequent occurrence as of and to are prevented from fixing themselves in the close of a sentence; though that be a situation they naturally incline to, where they favour the easy fall of the voice, in a familiar cadence; and from which nothing but the solemnity of an address from the pulpit ought to dislodge them; as in any other place they often give too great a stiffness and formality to a sentence.

While Priestley and Lowth may have influenced students of their grammars to attend more cautiously to this stylistic feature, many scholars, including Beal (2004:110); Crystal (2003:194); Nevalainen (2006:41); Hitchings (2011:59); O'Conner \& Kellerman (2010:21); Yáñez-Bouza (2008:251) attribute the creation of the "rule" to the poet and dramatist John Dryden, who lived a century earlier. Lynch (2009:28) tells us that Dryden (1631-1700) had "received the best education England had to offer," having attended Westminster School under the tutelage of "the legendary Richard Busby" (who had also taught philosopher John Locke and scientist Robert Hooke), and then received his B.A. (at the top of his class) at Trinity College in Cambridge. Dryden became a successful poet, playwright, and critic of other writers.

Fowler \& Burchfield (1996:617) explain that one of the writers Dryden criticized was Ben Jonson, whose Catiline (1611) contained the following line: “'The bodies that those souls were frighted from'." Dryden wrote that the placement of a preposition at the end of the sentence was "“a common fault with him, and which I have but lately observ'd 
in my own writings."' These comments in Dryden's Defence of the Epilogue (1672) “[a]pparently ...set the myth going" (617).

Because of Dryden's stature as a gifted writer (indeed, he was made "England's poet laureate" in 1668, a position he held for 20 years), it is interesting to note the many revisions he later made to one of his own essays. Lynch (2009:31) points out that over a century after the revised version of "Of Dramatick Poesie, an Essay" was published, critic Edmond Malone compared Dryden's first edition, published in 1668, with the second edition, which came out in 1684. Lynch describes some of these revisions as being "the sorts of things any writer might do when given the chance to revise." Dryden clarified ambiguities and exchanged outdated terms for more modern versions. He changed many instances of upon to simply on, and who to whom, among other improvements. Lynch notes that "the most curious class of corrections" was the "relocating [of] end-of-sentence prepositions to the beginning of a phrase" (31). Textual notes provided in a collection of Dryden's works (Dryden, Monk \& Maurer 1972) list numerous pages of the revisions between Dryden's first, second, and third editions of this essay. For example, the second edition substitutes "of which none boast in this" for "which none boast of" (491) and "on whom the story is built" for "whom all the story is built upon" (492). These are just two of dozens of examples.

What would have caused Dryden to make these changes? Crystal (2003:194) comments that Dryden's revision of the end-of-sentence prepositions "shows the influence of Latin grammar, where prepositions usually preceded nouns." In fact, Hitchings (2011:58) has noted Dryden's "habit" of translating his prose from English into 
Latin and back into English to ensure its correctness and "to assay the purity of his English.” Hitchings (2011:59) assesses Dryden's revisionist efforts as follows:

In pruning his own prose, Dryden had invented a rule. The circumstances of its invention had eluded everyone up till Malone, but the fact of its existence had not. People simply followed Dryden's example. It impressed eighteenth-century grammarians, and by the end of that century the stranded preposition was conventionally viewed as a grave solecism.

But even though Dryden certainly drew a lot of attention to the "stranded preposition,' it has been pointed out by Yáñez-Bouza (2008:270) that he was not the first to criticize the usage, but rather it may have been a teacher and writer by the name of Joshua Poole. Dryden's criticism of Jonson did not appear in print until 25 years after Poole's grammar, The English Accidence, was published. Poole and Alston (1967) list the first edition's publication date in 1646, with reprints following in 1655, 1662, and 1670.

In Poole and Alston (1967 [1646]:38), we find instruction regarding prepositions at the end of a sentence appearing as the first of "Two generall necessary Rules" at the end of the grammar:

If the signe of a case be farre off from the verb, or after the noune, the sense must direct a man to place the words in their naturall order; and if any thing be understood, it must be supplied out of the sense: as, To whom did you give your book to? i. to whom. What is hee good for? i. for what. This is the man I told you of; i. of whom I told you (Emphasis mine).

Poole's reference to 'the signe of a case' is a reference to the grammatical system of Latin, which uses different endings to indicate the case (the function) of nouns, 
pronouns, and adjectives in a sentence. Goldman \& Szymanski (1993:14) point out that in Latin, "[w]ord order alone rarely shows the function of nouns within a sentence. Instead, the different endings of the Latin nouns indicate the changes called case." In English, however, "the order of words in a sentence signals the function of the nouns and hence shows the meaning of the whole sentence" (13). It would seem impossible to understand or use Latin without a clear understanding of the concept of case, since using the wrong case endings might change the meaning of a sentence. But many individuals speak and write English without realizing that they are making a distinction between different cases. The following sentence illustrates three: The boy's sister found my keys.

The word sister is the subject of the sentence. In English, we refer to the subject of a sentence as being in the nominative (or subjective) case. (Latin uses the term nominative case also.) The modifier boy's indicates possession by the <'s >, so in English we would label the word as reflecting the possessive case. (Latin uses the term genitive case.) Finally, the word keys (which is the direct object of the verb found) is said to be in the objective case. (In Latin, the direct object of a verb appears in the accusative case.) In addition to the nominative, genitive, and accusative cases, Goldman \& Szymanski

(1993:15) list the dative and the ablative cases among the "five main cases" of Latin, with a brief mention of the other two: the vocative case and the locative case.

What was the 'signe of a case' that Poole was referring to? In Latin, of course, the sign of a case is the 'ending' of the word in question. Enkvist (1975:288) explains that "the idea of English 'signs' seems to have been borrowed by English grammarians from a long classroom tradition in the teaching of Latin." Enkvist cites a few examples of these " "signs' or prepositions" in English from Leech (1605): of, which signifies "the 
genitive case," and answers "the question, whose or whereof..." ; and to, which signifies “the Dative case..." So, in English, the 'sign' may be the preposition used in a construction with a noun or a verb, but as Enkvist (1975:287) further points out, a 'sign' or "token" (Lily used both terms) may be "the sum total of clues that enable us to identify case forms, rather than English prepositions only."

But was Poole really criticizing the 'stranded preposition' usage, as Yáñez-Bouza (2008) claims? The chapter in which this 'necessary rule' appears is entitled Certain Rules for the easier turning of English into Latine. In this chapter, Poole \& Alston (1969 [1646]:24) provide detailed observations regarding how some specific English words, forms, and constructions should be "made into Latine" (translated into Latin). Many of the words Poole lists are prepositions, including of, to, with, for, at, but, by, on, upon, in, to name just a few. He also includes "Rules concerning Pronounes" in this chapter. However, the goal of this chapter, and of the entire text, is revealed in the preface, where Poole says:

My drift and scope therefore is, to have a childe so well verst in his Mothers tongue, before he meddle with Latine, that when he comes to the construing of a Latine Authour, he shall from the signification of his words in construing, be in some good measure able to tell distinctly what part of Speech every word is, though he be not able to parse, varie, or give any other account of one word in his lesson; and when he is put to translation, or making of Latine, he shall know from his English, both what part of Speech every word is, and what Syntaxis, or ordering it 
should have in Latine, though in the meane time hee never heard of one Latine word...

Therefore, in Poole's 'necessary rule' regarding a situation in which 'the signe of a case be farre off from the verb, or after the noune, the sense must direct a man to place the words in their naturall order', it seems likely that he is simply continuing his instructions for translating English passages into Latin, not proscribing against the English pattern, or as Lowth (1967 [1762]:127) calls it, 'an Idiom which our language is strongly inclined to'.

But what does Poole mean when he says 'to place the words in their naturall order'? According to Enkvist (1975:285), "the concept of 'natural word order' ...had been defined in many different ways by logicians, grammarians and rhetoricians on various grounds brought from their respective disciplines..." He explains that "[t]he ordo naturalis was gradually equated with a basic word-order pattern based on the sequence subject-verb-object.” Further, Enkvist (1975:285-286) discusses how the ordo naturalis gained in significance as soon as Latin was taught as a foreign language. Latin patterns were now contrasted with the patterns of vernaculars, some of which—like English—made use of a basic word order closely resembling the 'natural order'. For the English schoolboy, therefore, the manipulation of natural and artificial order was a highly practical rather than theoretical exercise. If the translation went from Latin into English, the constituents of the Latin sentence had first to be identified with the aid of their case endings and concords, and then moved into their natural order, from which they could be directly translated into 
English. And if the translation went from English into Latin, the natural order helped construers to identify the functions of the English constituents and thus to give them their proper Latin forms. The Latin was first conceived in natural order, which was then turned into an artificial order if necessary, by moving constituents according to the demands of largely rhetorical principles. Thus the ordo naturalis turned into something like a linguistic universal, but—for once—a universal not based on the surface structures of rhetorical Latin.

So, it seems that Poole may not have been criticizing the oft-used English pattern of placing a preposition at the end of a sentence, as has been previously thought, at least not directly. And while many modern grammarians and teachers of English may continue to teach and to enforce the 'rule,' some scholars (Close 1992; Parrott 2010, among many others), have tried to influence the academic community toward a more tolerant approach. Even some of our modern dictionaries and usage guides offer a lessprescriptive view of the usage. The Oxford American Dictionary \& Thesaurus (2009:1016) provides the following definition and explanation:

Preposition: a word used with a noun or pronoun to show place, position, time, or method. USAGE: A preposition (a word such as from, to, on, after, etc.) usually comes before a noun or pronoun and gives information about how, when, or where something has happened (she arrived after dinner). Some people believe that a preposition should never come at the end of a sentence, as in where do you come from?, and that you should say from where do you come? instead. However, this can result in English that 
sounds very awkward and unnatural, and is not a rule that has to be followed as long as the meaning of what you are saying is clear.

The American Heritage Book of English Usage (1996:27) points out that "English syntax not only allows but sometimes even requires final placement of the preposition, as in We have much to be thankful for or That depends on what you believe in." In addition, this guidebook comments that "[e]ven sticklers for the traditional rule can have no grounds for criticizing sentences such as I don't know where she will end up or It's the most curious book I've ever run across..." since

in these examples, up and across are adverbs, not prepositions. You can be sure of this because it is impossible to transform these examples into sentences with prepositional phrases. It is simply not grammatical English to say I don't know up where she will end and It's the most curious book across which I have ever run.

This guidebook also mentions that after John Dryden "promulgated the doctrine that a preposition may not be used at the end [of] a sentence", it was "refined" by "[g]rammarians in the $18^{\text {th }}$ century... and the rule has since become one of the most venerated maxims of schoolroom grammar" (27). Less than a decade later, The American Heritage Guide to Contemporary Usage and Style (2005:372), which on the inside appears to be a newer version of the 1996 publication, adds the following note: "There has been some retreat from this position in recent years, however-what amounts to a recognition of the frequency with which prepositions end sentences in English." This comment is the only major change from the entry in the 1996 edition. 
The point here seems to be that general use or "custom," as Priestley (1761:vi) calls it, has led to a change in the acceptability of certain end-of-sentence prepositions, especially in situations in which: a) the meaning is clear; b) the wording seems natural; and c) rewording to avoid the construction would result in an awkward or "pompoussounding" (Bernstein 1965:343) sentence. Huddleston (1997:338) comments that "[i]n general it is those which are short, frequent, and have 'grammatical uses' that are most easily stranded--in, on, of, at, with, etc., rather than beside, throughout, despite, underneath, and the like."

In a twentieth-century guide for writers, Perrin (1965:752-753) suggests that while "it was once fashionable for textbooks to put a stigma upon prepositions standing at the end of their constructions..." this pattern

is a characteristic English idiom, even though it runs contrary to our usual tendency to keep words of a construction close together. In fact it is so generally the normal word order that the real danger is in clumsiness from trying to avoid a preposition at the end of a clause or sentence... (753).

This mention of an 'English idiom' reminds us again of the observations recorded by some of the above-mentioned grammarians of the eighteenth century. These grammarians seemed to recognize the importance of allowing English to be English—not simply as a word-for-word translation of the highly revered classical Latin, but as a language with its own features, expressions, and even idiosyncrasies. It is apparent that over time some of the more popular grammar texts became prescriptive tools that offered teachers a rubric against which student writing could be measured. However, we have seen in the history of the stricture regarding preposition stranding that emphasizing 
natural expression and clarity of meaning should take precedence over rigid adherence to a 'rule' that was based on the grammar of Latin. 


\section{CHAPTER VIII}

\section{SUMMARY AND PEDAGOGICAL IMPLICATIONS}

The preceding chapters of this thesis have offered a brief overview of the historical events that contributed to the rise of "Standard English" that is associated with the eighteenth century. This final chapter endeavors to summarize the effects of the pedagogical approach that developed as a natural progression of the enforcing of the "rules" promoted by grammar texts and dictionaries of the early modern period up through the present day.

Martin \& Rulon (1973:43) depict the study of English grammar in early American schools as following the Latin model, which emphasized "sentence analysis in which the sentences were parsed through the identification of parts of speech or were diagrammed according to an elaborate system developed by Alonzo Reed and Brainerd Kellogg.” Additionally, grammar study involved memorizing rules of proper usage and demonstrating that knowledge by choosing "the correct answer" while completing “countless exercises."

As discussed in an earlier chapter, dictionaries and grammars that upheld the use of commonly accepted standards of proper usage became the established "authorities" of language use. Grammarians such as Joseph Priestley (who wrote The Rudiments of English Grammar) apparently did not hold as much sway as the popular "Bishop" Robert Lowth and the well-known Lindley Murray (who adapted much of Lowth's work into his 
own text). Why? Apparently many readers (then and now) have perceived Priestley's grammar as more descriptive than prescriptive (Bragg 2011:204). And during the eighteenth and nineteenth centuries, a period in which social status was often measured by the "correctness" of one's speech and writing, those persons wishing to improve their standing in society wanted a guidebook or manual to study that could help them achieve this goal (Mugglestone 1997; Tieken-Boon Van Ostade 2011; Beal 2004; and TiekenBoon Van Ostade 2010a).

Grammars such as Lowth's Short Introduction to English Grammar and Murray's English Grammar have long been assumed to have based their "rules" of grammar and usage heavily on the precepts set forth in Latin grammars, with which all scholars of that period were undoubtedly familiar (Wardaugh 1999; Martin \& Rulon 1973). While this assumption has been questioned in some of the literature (NCTE 1962; Chapman 2008, Tieken-Boon Van Ostade 2008b, and Yañez-Bouza 2008), it is widely accepted that the stylistic approach of Lowth's and Murray's (and many other) grammars was patterned after that of typical Latin grammars. By this, I simply mean that the presentation of the earliest grammars written by Lowth (1762) and Murray (1795) is very similar to that of the Latin grammar written by Lily (1633), who (writing in English) introduces the grammar of Latin by distinguishing between eight parts of speech. Lowth and Murray follow this pattern in their grammars of English, going so far as to include a comparison of the case distinction of nouns and pronouns between Latin and English.

Ronald Wardaugh (1999:123) describes the legacy of eighteenth century grammarians such as Lowth and Murray as having "dominated the teaching of the English language throughout the nineteenth century [and] retained considerable influence 
well into the twentieth" as well as underlying "much such teaching today where it occurs."

Many of the current K-12 teachers in America have undoubtedly sat under that influence, and indeed, are in the process of carrying on the perceived traditions of eighteenth century prescriptive grammarians and teachers. What alternative do they have?

Martin \& Rulon (1973:234) indicate that Robert Pooley advocates "[a] middle road," something he refers to as 'an enlightened prescriptivism,' in which 'teachers ignore distinctions between shall and will, split infinitives, like as a conjunction... and other minute matters." Instead, he proposes that teachers "concentrate...on the standard use of pronouns, verb tenses, and agreement with subject, the elimination of double negatives, etc."

Pooley's recommendation seems to reflect the goals of Otto Jespersen (1933:5), whose words in his 1909 "bigger Grammar" were reiterated in the preface to his Essentials of English Grammar:

'It has been my endeavor in this work to represent English grammar not as a set of stiff dogmatic precepts, according to which some things are correct and others absolutely wrong, but as something living and developing under continual fluctuations and undulations, something that is founded on the past and prepares the way for the future, something that is not always consistent or perfect, but progressing and perfectible-in one word, human'. 
Jespersen's words, first written over a century ago, bear attentive study by the English teachers of the twenty-first century and beyond. However, some teachers may be blissfully unaware that by their focused attention to the "rules" of English grammar they are perpetuating an ideology that may not adequately represent current knowledge and linguistic understanding.

Unfortunately, this is not a new issue. The topic of English grammar has long been a bugaboo of school administrators and faculty alike. As amazing as it may sound, since almost the middle of the twentieth century scholars, educators, and other interested parties have been involved in arguments and heated discussions, and some have even begun "revolutions" over the subject. Kolln \& Hancock (2005:11) discuss how the 'revolution in grammar' that Francis (1954) announced was just one of a wave of changes "on the horizon." Francis (1954:299) was referring to "the new grammar," which differs from "traditional grammar" by its "application to English of methods of descriptive analysis originally developed for use with languages of primitive peoples." The overview of the history of grammar teaching in the twentieth century provided by Kolln \& Hancock (2005:13) details the effects on English grammar pedagogy of the influences of linguistic science, the focus on teaching literature over language structure, the "dynamic rather than stable" nature of usage related to "correctness," as shown by Sterling A. Leonard and C.C. Fries, and the emphasis on humanistic thought. They also discuss the continuing debate over the value of teaching grammar as a means to improve writing. David Mulroy (2003) covers similar territory in his important work, The war against grammar. His first chapter, entitled America the Grammarless, sets the scene for the remainder of the book, a discussion of the study of grammar teaching and the history 
surrounding the dropping of grammar from the curriculums of schools in England and the United States.

What seems to have happened in this country, as well as in England, was a drastic reaction to new theories about education, and specifically, about the teaching of English grammar. The effects of the new grammar and the new pedagogical emphases have been felt over the last few decades, during which, at least in the U.S., national legislation and the focus on the results of standardized testing have re-established the necessity of teaching grammar. The problem has manifested itself, if I may align with Francis (1954:312), in a situation in which "many people are called upon to teach grammar whose knowledge of the subject is totally inadequate."

But this kind of "teaching" does not have to continue. What I am advocating, like Jespersen, Pooley, and many others before me, is a comprehensive approach that embraces all of the components of our mother tongue: an approach that studies its diachronic development and the historical and socio-linguistic influences that have transformed English into "Globish," what Robert McCrum (2010:246) has defined as " "the worldwide dialect of the third millennium'."

I agree with Greenbaum (1988:27): "Schools should teach about language, and specifically about the English language, for a variety of reasons. First, an understanding of the nature and functioning of language is a point of general knowledge that students should acquire about themselves and the world they live in." In light of the ever-changing world in which we live, this statement holds true, perhaps now more than ever before.

In the preface to Understanding Grammar: a Linguistic Introduction, Thomas Payne (2010:xii) sums up the overall message of this thesis very nicely: 
The grammar of a language is a dynamic, constantly changing set of habit patterns that allows people to communicate with one another. For some reason, many in academia and language teaching seem to have lost sight of this common sense truth, preferring to teach grammar as though it were an object, outside of human beings in society, consisting of absolute categories and rules. This misperception has led to a deep tension between theoreticians and the practical needs of language teachers, whose students often come to believe that grammar is a tedious classroom subject, to be endured as a kind of rite of passage, rather than a key to the amazing world of human communication.

I love the image of grammar as a key that can unlock the door to communication. What if all of the teachers of English in the United States held that vision for their classes? And, instead of focusing on rules and precepts that dictate "correct" versus "incorrect" language usage, what if all of these teachers instilled in their students a curiosity about their native (or adopted) language and a thirst for understanding about language change, variation, and history? I daresay the English classroom would never be the same again. 


\section{REFERENCES}

Aaron, J. (1995). The Little, Brown compact handbook. New York: HarperCollins College Publishers.

Addison, J. (1711). The Spectator 135. Morley, H. (ed.). (1891). Web.

Aitken, G. (ed.). (1899). The Tatler. Vol. 1. New York: Hadley \& Mathews. London: Duckworth \& Co.

Bailey, A. (1667). Spightful sister. iii.i. 26. The Oxford English Dictionary. $3^{\text {rd }}$ edn. (2010). Entry for 'be'. Oxford University Press.

Bailey, G. \& Thomas, E. (1998). Some aspects of African-American vernacular English phonology. Bailey, G., Baugh, J., Mufwene, S., \& Rickford, J. (eds.). AfricanAmerican English: Structure, History and Use. New York: Routledge.

Bailey, R. (2010). Variation and change in eighteenth-century English. Hickey, R. (ed.). Eighteenth century English. New York: Cambridge University Press.

Baker, P. (2012). Introduction to Old English. 3rd edn. Oxford: Wiley-Blackwell.

Barber, C. Beal, J., \& Shaw, P. (2009). The English language: A historical introduction. Cambridge: Cambridge University Press.

Bauer, L. (1994). Watching English change: An introduction to the study of linguistic change in standard Englishes in the twentieth century. New York: Longman Group Limited.

Bauer, L. (1998). Myth 16: You shouldn't say 'It is me' because 'me' is accusative. Bauer, L., \& Trudgill, P. (eds.). Language myths. London: Penguin Books.

Bauer, L., \& Trudgill, P. (eds.). (1998). Language myths. London: Penguin Books.

Baugh, A. \& Cable, T. (2002). A history of the English language. London: Routledge.

Beal, J. (2004). English in modern times, 1700-1945. London: Arnold.

Bernstein, T. (1965). The careful writer: A modern guide to English usage. New York: Atheneum. 
Beukema, F. (1999). Five ways of saying no: The development of sentential negation in English in a government and binding perspective. Tieken-Boon Van Ostade, I., Tottie, G., \& Van Der Wurff, W. (eds.). Negation in the history of English. New York: Mouton de Gruyter.

Bex, T., \& Watts, R. (eds.). (1999). Standard English: The widening debate. London: Routledge.

Blank, P. (2008). The Babel of Renaissance English. Mugglestone, L. (ed.). The Oxford history of English. New York: Oxford University Press.

Bragg, M. (2011). The adventure of English: The biography of a language. New York: Arcade Pub.

Brice-Heath, S. (1980). Standard English: Biography of a symbol. Shopen, T. \& Williams, J. (eds.). Standards and dialects in English. Washington, D.C.: Center for Applied Linguistics.

Brown, G. (1855). Kiddle, H. (2008). The first lines of English grammar. BiblioBazaar.

Bucholz, R. \& Key, N. (2004). Early modern England 1485-1714: A narrative history. Malden, MA: Blackwell Publishing.

Buck, G. (1909). Make-Believe Grammar. The School Review. 17 (1). 21-33. The University of Chicago Press.

Burridge, K. (2004). Blooming English: Observations on the Roots, Cultivation and Hybrids of the English Language. New York: Cambridge University Press.

Burton, G. Imitation. Silva Rhetoricae. Brigham Young University. http://rhetoric.byu.edu/pedagogy/Imitation.htm. (7 July, 2013).

Cameron, D. (1995). Verbal hygiene. New York: Routledge.

Campbell, L. (2004). Historical linguistics: An introduction. $2^{\text {nd }}$ edn. The MIT Press.

Chapman, D. (2008). The eighteenth-century grammarians as language experts. TiekenBoon Van Ostade, I. (ed.). Grammars, grammarians, and grammar-writing in eighteenth-century England. New York: Mouton de Gruyter.

Chaucer, G.; Mann, J. (ed.). (2005). The Canterbury Tales. New York: Penguin Group (USA) Inc.

Chaucer, G.; in Greenblatt, S. \& Abrams, M. H. (eds.). (2006). The Norton anthology of English literature. New York: W.W. Norton \& Company. 
Cheshire, J. (1981). Variation in the use of ain't in an urban British dialect. Language in Society. New York: Cambridge University Press. 10 (3). 365-381.

Cheshire, J. (1999a). English negation from an interactional perspective. Tieken-Boon van Ostade, I., Tottie, G., \& Wurff, W. (eds.). Negation in the history of English. Berlin: Mouton de Gruyter.

Close, R.A. (1992). A teacher's grammar: The central problems of English. London: Language Teaching Publications.

Corrie, M. (2008). Middle English—dialects and diversity. Mugglestone, L. (ed.). The Oxford history of English. New York: Oxford University Press.

Crystal, D. (1980). A first dictionary of linguistics and phonetics. London: A. Deutsch.

Crystal, D. (2003). The Cambridge encyclopedia of the English language. 2nd edn. New York: Cambridge University Press.

Curzan, A. \& Adams, M. (2012). How English works: A linguistic introduction. $3^{\text {rd }}$ edn. New York: Longman.

Daniel, E. (1901). The grammar, history, and derivation of the English language. London: National Society's Depository.

Davidson, M. (2006). Right, wrong, and risky: A dictionary of today's American English usage. New York: W.W. Norton \& Co.

Davis, J. (1994). Mother tongue: How humans create language. New York: Carol Publishing Group.

Denham, K., \& Lobeck, A. (2009). Linguistics for everyone: An introduction. Boston, MA: Wadsworth Publishing.

Denison, D. (1998). Syntax. The Cambridge history of the English language. Vol. IV, 1776-1997. Romaine, S. (ed.). Cambridge: Cambridge University Press.

Dickens, C. (2012). Oliver Twist. First Vintage Classics Edition. New York: Vintage Books.

Dictionary of Old English Web Corpus. (2011). Entry for 'ask'. The Dictionary of Old English. University of Toronto.

Dryden, J. (1972). S. Monk \& A. Maurer (eds.). The Works of John Dryden, Volume XVII: Prose, 1668-1691: An essay of dramatick poesie and shorter works. Berkley, CA: University of California Press. 
Enkvist, N. (1975). English in Latin guise: A note on some Renaissance textbooks. Historiographia Linguistica. II: 3. 283-298.

Finegan, E. (1980). Attitudes toward English usage: The history of a war of words. New York: Teachers College Press.

Finegan, E. (1998). English Grammar and Usage. Romaine, S. (ed.). The Cambridge history of the English language. Vol. IV, 1776-1997. Cambridge: Cambridge University Press.

Fisher, J. (1992). The importance of Chaucer. Carbondale: Southern Illinois University Press.

Fisher, J. (1996). The emergence of standard English. Lexington: University Press of Kentucky.

Fowler, H. R., \& Aaron, J. E. (1992). The Little, Brown handbook. New York: HarperCollins.

Fowler, H. W. (ed.). Burchfield, R. W. (ed.). (1996). The new Fowler's modern English usage. Oxford: Clarendon Press.

Fowler, H. W. (ed.). Burchfield, R. W. (ed.). (2000). The new Fowler's modern English usage. New York: Oxford University Press.

Francis, N. (1954). Revolution in grammar. Quarterly Journal of Speech. 40 (3). 299312.

Fromkin, V., Rodman, R. \& Hyams, N. (2007). An introduction to language. Boston, MA: Thomson Wadsworth.

Fulk, R., \& Cain, C. (2003). A history of Old English literature. Malden, MA: Blackwell.

Garner, B. (2000). The Oxford dictionary of American usage and style. New York: Oxford University Press.

Goldman, N., \& Szymanski, L. (1993). English grammar for students of Latin: The study guide for those learning Latin. Ann Arbor, MI: Olivia and Hill Press.

González-Díaz, V. (2008). English adjective comparison: A historical perspective. Amsterdam: John Benjamins Publishing Co.

Graddol, D., Leith, D., \& Swann, J. (1996). English history, diversity and change. New York: Routledge.

Greenbaum, S. (1988). Good English and the grammarian. London: Longman.

Greenbaum, S. (1996). The Oxford English grammar. Oxford: Oxford University Press. 
Greenfield, S. \& Calder, D. (1986). A new critical history of Old English literature. New York: NYU Press.

Haugland, K. (1995). Is't allowed or ain't it? On contraction in early grammars and spelling books. Studio Neophilogica. 67 (2). 165-184.

Herndon, J. (1976). A survey of modern grammars. $2^{\text {nd }}$ ed. New York: Holt, Rinehart and Winston.

Hickey, R. (2010). Attitudes and concerns in eighteenth-century English. Hickey, R. (ed.) Eighteenth century English. New York: Cambridge University Press.

Hitchings, H. (2011). The language wars: A history of proper English. New York: Farrar, Straus and Giroux.

Hogg, R. (2009). Old English dialectology. Van Kemenade, A., Los, B. (eds.). The handbook of the history of English. Malden, MA: John Wiley \& Sons.

Hollander, J. (eds.). (1993). 21st century grammar handbook. New York: Dell Pub.

Hollis, S. (2012). Anglo-Saxon secular learning and the vernacular: an overview. Secular Learning in Anglo-Saxon England, ed. Chardonnens and Carella Amsterdamer Beiträge zur älteren Germanistik. 69. 1-43.

Hook, J. \& Mathews, E. (1959). Changes in the English language. Dean, L. \& Wilson, K. (eds.). Essays on Language and Usage. New York: Oxford University Press.

Hopper, P. (1999). A short course in grammar. New York: W. W. Norton \& Co.

House, H. \& Harman, S. (1950). Descriptive English grammar. Englewood Cliffs, N.J.: Prentice-Hall.

Huddleston, R. (1997). Introduction to the grammar of English. Cambridge [Cambridgeshire]; Cambridge University Press.

Huddleston, R. \& Pullum, G. (2002). The Cambridge grammar of the English language. New York: Cambridge University Press.

Hudson, R. (2000). I amn’t. Language. 76 (2). 297-323. Linguistic Society of America.

International Reading Association \& National Council of Teachers of English. (1996). Standards for the English Language Arts. USA: International Reading Association/National Council of Teachers of English.

Jeffcoat III, J. (2002). English Bible History. http://www.greatsite.com/timeline-englishbible-history/. (17 June, 2011).

Jespersen, O. (1917). Negation in English and other languages. København: A. F. Høst. 
Jespersen, O. (1928). A Modern English Grammar on historical principles. Volume 5. Heidelberg: C. Winter.

Jespersen, O. (1933). Essentials of English Grammar. New York: Henry Holt \& Co.

Jones, R. (1953). The triumph of the English language. Stanford, CA: Stanford University Press.

Joseph, Sister M. (2002). McGlinn, M. (ed.). The Trivium: The liberal arts of logic, grammar, and rhetoric. Philadelphia, PA: Paul Dry Books.

Judge, G. (2009). The Timeline history of the English language. USA: Cogno Graphica Publishing.

Klammer, T., Schulz, M. \& Della Volpe, A. (2010). Analyzing English grammar. New York: Longman.

Knowles, G. (1997). A cultural history of the English language. London: Arnold.

Kolln, M. \& Hancock, C. (2005). The story of English grammar in United States schools. English Teaching: Practice and Critique. 4 (3). 11-31.

Krutch, J. (1969). Who says it's proper English? Doster, W. (ed.). First perspectives on language. New York: American Book Co.

Law, V. (1987). Anglo-Saxon England: Ælfric's “Excerptiones de Arte Grammatica Anglice". Histoire Épistémologie Langage: 47-71.

Leith, D. (2003). A social history of English. New York: Routledge.

Leonard, S. (1962). The doctrine of correctness in English usage, 1700-1800. New York: Russell \& Russell, Inc.

Lerer, S. (2007). Inventing English: A portable history of the language. New York: Columbia University Press.

Lily, W. (1574). A shorte introduction of grammar generallye to be vsed: Compyled and set forth, for the bringing vp of all those that intende to attaine the knowledge of the Latine tongue. Imprinted at London : By the assignes of Frauncis Flowar. Reprint. USA: EEBO Editions, ProQuest.

Lily, W. (1633). A shorte introduction of grammar generallye to be vsed: Compyled and set forth, for the bringing vp of all those that intende to attaine the knowledge of the Latine tongue. Imprinted at London: By the assignes of Bonham Norton. Reprint. USA: EEBO Editions, ProQuest. 
Lippi-Green, R. (2007). English with an accent: Language, ideology, and discrimination in the United States. New York: Routledge.

Lowth, R. (1762, 1967). A short introduction to English grammar. Menston (Yorks.): Scolar Press.

Luhman, R. (1990). Appalachian English stereotypes: Language attitudes in Kentucky. Language in Society. 19 (3). 331-348.

Lunsford, A., Matsuda, P., Tardy, C., Ede, L. (2011). The St. Martin's handbook. $7^{\text {th }}$ edn. Boston: Bedford/St. Martins.

Lynch, J. (2009). The Lexicographer's dilemma: The Evolution of 'proper' English, from Shakespeare to South Park. New York: Walker \& Company.

Machan, T. (2009). Language anxiety. New York: Cambridge University Press.

Martin, C. \& Rulon, C. (1973). The English language yesterday and today. Boston: Allyn and Bacon, Inc.

Matthews, W. (1937). Some eighteenth-century vulgarisms. The review of English studies. 13 (51). 307-325. Oxford University Press.

McAdam, Jr., E. \& Milne, G. (1964). Samuel Johnson's dictionary: A modern selection. New York: Pantheon Books.

McClendon, G. (2004). Ax or Ask: The African American guide to better English. http://www.mcclendonreport.com. (6 June, 2011).

McCrum, R. (2010). Globish: How the English language became the world's language. New York: W.W. Norton \& Company.

McDavid, R. (1941). Ain’t I and Aren't I. Language. 17 (1). 57-59. Linguistic Society of America.

McGrath, A. (2002). In the beginning: The story of the King James Bible and how it changed a nation, a language, and a culture. New York: Anchor Books.

McKay, J.; Hill, B.; Buckler, J. (1987). A history of Western society. Boston, MA: Houghton Mifflin.

McLaughlin, J. (1970). Aspects of the history of English. New York: Holt, Rinehard \& Winston, Inc.

McWhorter, J. (2008). Our magnificent bastard tongue: The untold history of English. New York: Gotham Books. 
Merriam-Webster Dictionary of English usage. (1989). Springfield, MA: MerriamWebster, Inc.

Michael, Ian. (2010). English grammatical categories and the tradition to 1800. New York: Cambridge University Press.

Millward, C. M. (1996). A biography of the English language. Boston, MA: Wadsworth.

Milroy, J. \& Milroy, L. (1999). Authority in language: Investigating standard English. New York: Routledge.

Milroy, L. (1998). Myth 12: Bad grammar is slovenly. Bauer, L. \& Trudgill, P. (eds.). Language myths. London: Penguin Books.

Mitchell, L. (2001). Grammar wars: Language as cultural battlefield in 17th and 18th century England. Aldershot, Hampshire: Ashgate.

Moore, J. L. (1970). Tudor-Stuart views on the growth status and destiny of the English language. College Park, MD: McGrath Publishing Company.

Moorwood, J. (2000). A Latin grammar. Oxford: Oxford University Press.

Mount, H. (2007). Carpe Diem: Put a little Latin in your life. New York: Hyperion.

Mugglestone, L. (1997). 'Talking Proper': The rise of accent as social symbol. Oxford: Clarendon Press.

Mugglestone, L. (2003). 'Talking Proper': The rise of accent as social symbol. New York: Oxford University Press.

Mulroy, D. (2003). The war against grammar. Portsmouth, NH: Boynton/Cook Publishers.

Murray, Lindley. (1968). English grammar, 1795. Menston (Yorks.): The Scolar Press Limited.

NCTE. (1962). Grammatical analysis in the $17^{\text {th }}$ and $18^{\text {th }}$ centuries. College Composition and Communication. 13 (3). 70. Annual meeting. Chicago. National Council of Teachers of English. http://www.ncte.org/cccc/ccc/issues/v13-3. (6 June, 2011).

Nevalainen, T. (2006). An introduction to early Modern English. Oxford: Oxford University Press.

Nevalainen, T., \& Raumolin-Brunberg, H. (2003). Historical sociolinguistics: Language change in Tudor and Stuart England. London: Longman.

O'Conner, P. (2003). Woe is I: The grammarphobe's guide to better English in plain English. New York: Riverhead Books. 
O’Conner, P. \& Kellerman, S. (2010). Origins of the specious. New York: Random House.

Ostler, N. (2007). Ad infinitum: a biography of Latin. New York: Walker \& Co.

Oxford American Dictionary \& Thesaurus. $2^{\text {nd }}$ edn. (2009). New York: Oxford University Press.

Oxford University Press. 2011. Entry for 'grammar'. The Oxford English Dictionary online. Oxford University Press.

Oxford University Press. 2013. Entry for 'ask'. The Oxford English Dictionary online. Oxford University Press.

Oxford University Press. 2010. Entry for 'be'. The Oxford English Dictionary online. Oxford University Press.

Parrott, M. (2010). Grammar for English language teachers. Cambridge: Cambridge University Press.

Partridge, E. (1973). Usage and abusage: A guide to good English. Harmondsworth, Middlesex, England: Penguin Books in association with Hamish Hamilton.

Partridge, E., Dalzell, T., \& Victor, T. (eds.). (2008). The Concise New Partridge Dictionary of Slang and Unconventional English. London: Routledge.

Payne, T. (2010). Understanding English grammar: A linguistic introduction. New York: Cambridge University Press.

Perrin, P. (1965). Writer's guide and index to English. 4th edn. Chicago: Scott, Foresman and Company.

Poole, J. (1967). The English accidence, 1646. Leeds, Scolar Press.

Pooley, R. (1957). Teaching English grammar. New York: Appleton-Century-Crofts.

Pooley, R. (1959). Historical backgrounds of English usage. Dean, L. \& Wilson, K. (eds.). Essays on Language and Usage. New York: Oxford University Press.

Priestley, Joseph. The rudiments of English grammar, 1761. Menston (Yorks.): Scolar P., 1969. Print.

Pyles, T. (1964). The origins and development of the English language. New York: Harcourt, Brace \& World.

Pyles, T. \& Algeo, J. (1993). The origins and development of the English language. Orlando, FL: Harcourt Brace \& Co. 
Richardson, M. (1980). Henry V, the English Chancery, and Chancery English. Speculum. 55 (4). 726-750.

Rickford, J. \& Rickford, R. (2000). Spoken soul: the story of Black English. New York: Wiley.

Romaine, S. (2000). Language in society: an introduction to sociolinguistics. $2^{\text {nd }}$ edn. New York: Oxford University Press.

Salmon, V. (1999). Orthography and punctuation. The Cambridge history of the English language, Vol III. Hogg, R., Lass, R. (eds.). New York: Cambridge University Press.

Saurio, A. (2010). "if you think me obstinate I can't help it": Exploring the epistolary styles and social roles of Elizabeth Montagu and Sarah Scott. Pahta, P.; Nevala, M.; Nurmi, A.; Palander-Collin, M. (eds.). Social Roles and Language Practices in Late Modern English. Philadelphia, PA: John Benjamins.

Schmitt, N. \& Marsden, R. (2006). Why is English like that? Historical answers to hard ELT questions. Ann Arbor, MI: The University of Michigan Press.

Shakespeare, W. (1975). William Shakespeare, the complete works: illustrated. New York: Gramercy Books.

Silverstein, M. (1979). Language structure and linguistic ideology. In The Elements: $a$ parasession on linguistic units and levels. Clyne, P., Hanks,W., \& Hofbauer, C. (eds.). Chicago: Chicago Linguistic Society.

Skinner, D. (2012). The story of ain't: America, its language, and the most controversial dictionary ever published. New York: Harper Collins.

Slade, B. (2009). Axing for trouble: Beowulf and metathesis. Blog. http://staefcraeft.blogspot.com/2009/10/beowulf-axes-questions.html. (10 October, 2009).

Stevens, M. (1954). The derivation of 'ain't'. American Speech. 29 (3). 196-201.

Strumpf, M., and Douglas, A. (2004). The grammar Bible: Everything you always wanted to know about grammar but didn't know whom to ask. New York: St. Martin's Griffin.

Swift, J. (1710). Journal to Stella, Letter ix. Cited in Stevens, M. (1954). The derivation of 'ain't'. American Speech. 29 (3). 196-201.

Swift, J. (1710). The Tatler. No. 230. http://www.ourcivilisation.com/smartboard/shop/swift/bckrstff/chap2.htm. (6 June, 2011). 
Swift, J. (1712). A proposal for correcting, improving and ascertaining the English tongue. London: Benjamin Tooke.

The American Heritage Dictionaries. (eds.). (1996). The American Heritage book of English usage: A practical and authoritative guide to contemporary English. Boston: Houghton Mifflin.

The American Heritage Dictionaries. (eds.). (2005). The American Heritage guide to contemporary usage and style. Boston: Houghton Mifflin.

Tieken-Boon Van Ostade, I. (2008a). English at the onset of the normative tradition. Mugglestone, L. (ed.). The Oxford history of English. New York: Oxford University Press.

Tieken-Boon van Ostade, I., Tottie, G., \& Wurff, W. (eds.). (1999). Negation in the history of English. Berlin: Mouton de Gruyter.

Tieken-Boon Van Ostade, I. (ed.) (2008b). Grammars, grammarians, and grammarwriting in eighteenth-century England. New York: Mouton de Gruyter.

Tieken-Boon van Ostade, I. (2009). An introduction to late modern English. Edinburgh, Great Britain: Edinburgh University Press.

Tieken-Boon Van Ostade, I. (2010a). Eighteenth century women and their norms of correctness. Hickey, R. (ed.) Eighteenth century English. New York: Cambridge University Press.

Tieken-Boon Van Ostade, I. (2010b). Lowth as an icon of prescriptivism. Hickey, R. (ed.) Eighteenth century English. New York: Cambridge University Press.

Tieken-Boon Van Ostade, I. (2011). The Bishop's Grammar: Robert Lowth and the rise of prescriptivism. Oxford: Oxford University Press.

Walker, J. (2005). The ain't constraint: Not-contraction in early African American English. Language Variation and Change. 17. 1-17.

Walsh, B. (2004). The elephants of style: A trunkload of tips on the big issues and gray areas of contemporary American English. New York: McGraw Hill.

Wardaugh, R. (1999). Proper English: Myths and misunderstandings about language. Malden, MA: Blackwell Publishers.

Warriner, J. (1982). English Grammar and Composition. Third course. New York: Harcourt Brace Jovanovich.

Watts, R. (2008). Grammar writers in eighteenth-century Britain: A community of practice or a discourse community? Tieken-Boon Van Ostade, I. (ed.). Grammars, 
grammarians, and grammar-writing in eighteenth-century England. New York: Mouton de Gruyter.

Webster, N. (1967 [i. e. 1968]). Dissertations on the English language, 1789. Menston (Yorks.): Scolar Press Limited.

White, L. (2009). King Alfred's English: A history of the language we speak and why we should be glad we do. Covington, GA: The Shorter Word Press.

Wilde, S. (1997). What's a schwa sound anyway? A holistic guide to phonetics, phonics, and spelling. Portsmouth, NH: Heinemann.

Willard, E. (1936). The origin of ain't. Word Study. XI. Letter to the editors. Merriam. Cited in Stevens, M. (1954). The derivation of 'ain't'. American Speech. 29 (3). 196-201.

Woolard, K. (1998). Introduction: Language ideology as a field of inquiry. In B. Schieffelin, K. Woolard \& P. Kroskrity (eds.). Language Ideologies: Practice and theory. New York: Oxford University Press, Inc.

Wright, J. \& Wright, E. (1914). Old English Grammar (Old English Edition). Oxford.

Wycherley, W. (1675). The country wife. Retrieved from: http://faculty.winthrop.edu/vorderbruegg/winthropweb/current/scripts/CountryWi fe--acting\%20version--revised.pdf

Yañez-Bouza, N. (2008). Preposition stranding in the eighteenth century: Something to talk about. Tieken-Boon Van Ostade, I. (ed.). Grammars, grammarians, and grammar-writing in eighteenth-century England. New York: Mouton de Gruyter.

Yule, G. (2010). The study of language. New York: Cambridge University Press. 